Revista lus et Praxis, Año 18, № 1, 2012, pp. 187 - 248

ISSN 0717 - 2877

Universidad de Talca - Facultad de Ciencias Jurídicas y Sociales

"Contradicción, imparcialidad e inmediación en la ley de enjuiciamiento civil española. Algunos problemas para la consolidación de estos principios en la práctica"

Fernando Santelices Ariztía

\title{
CONTRADICCIÓN, IMPARCIALIDAD E INMEDIACIÓN EN LA LEY DE ENJUICIAMIENTO CIVIL ESPAÑOLA. ALGUNOS PROBLEMAS PARA LA CONSOLIDACIÓN DE ESTOS PRINCIPIOS EN LA PRÁCTICA*
}

\author{
CONTRADICTION, IMPARTIALITY AND INMEDIACY IN SPANISH CIVIL \\ PROCEDURE ACT. SOME PROBLEMS FOR THE CONSOlidATION OF THIS \\ PRINCIPLES IN PRACTICE
}

Fernando Santelices Ariztía*

\begin{abstract}
RESUMEN
El presente trabajo constituye la investigación final realizada por el autor para el Máster en Ciencias Jurídicas en la Universidad Pompeu Fabra en Barcelona. El texto incorpora algunas correcciones para efectos de su publicación. En el mismo, se efectúa un análisis de la Ley de Enjuiciamiento Civil española (LEC) a partir de la observación de audiencias, la realización de entrevistas y la revisión de doctrina y jurisprudencia con la finalidad de verificar en la práctica la materialización de los principios de Oralidad, Contradicción e Inmediación que consagra la ley. El trabajo presenta una breve descripción del estado actual del sistema de justicia civil en España y de las principales audiencias consagradas en la LEC para los procesos declarativos. Luego, el autor describe y desarrolla una serie de aspectos problemáticos que, a su juicio, se presentan en la práctica a partir de ciertas normas de la LEC y desde las técnicas de litigación oral. Consciente de la influencia que representa la LEC para el proceso de reforma a la justicia civil en Chile el autor efectúa un breve repaso del proyecto de Código Procesal Civil chileno del año 2009, constatando como éste supera algunos de los problemas observados en la $L E C$ pero que a su vez mantiene otros, los que, a juicio del autor, pueden influir en la correcta implementación y desarrollo en la práctica de la reforma al proceso civil en Chile. Finalmente, se presentan algunas propuestas concretas para corregir y mejorar los problemas observados en la LEC. Como señala su autor, este trabajo tiene por finalidad constituir un aporte al debate sobre la reforma procesal civil, haciendo presente la importancia que tiene recoger las buenas y malas experiencias que en la práctica presentan otros sistemas procesales orales, incluyendo la reforma procesal penal chilena, dada la distancia que muchas veces se produce entre la teoría y la práctica.
\end{abstract}

\footnotetext{
*Trabajo recibido el 15 de noviembre de 2011 y aprobado el 20 de abril de 2012.

** Abogado, U. Diego Portales; Máster en Ciencias Jurídicas, U. Pompeu Fabra, Barcelona; Diplomado en Reforma Procesal Penal, Juicio Oral y Litigación, U. Diego Portales; Fiscal Adjunto del Ministerio Público, entre los años 2006-2010; experiencia docente en Litigación Oral y Reforma Procesal Penal en Chile, Argentina, Perú, Bolivia, México y Panamá. Correo electrónico: fsantelices@bbis.cl.
} 
ABSTRACT

This text is the final study conducted by the author for the Master's Degree in Legal Sciences at Barcelona's Universidad Pompeu Fabra en Barcelona. This text has been amended by the author for publishing purposes. In it, he develops an analysis of Civil Procedure Act (CPA) based on the observation of hearings, a series of interviews and a study of doctrine and case law designed to allow him to verify the use of the principles of oral procedures, contradiction, impartiality and immediacy laid out by the law. This study offers a brief description of the current state of the Spanish civil justice system and the main hearings set out in the CPA for declarative procedures. The author then describes and develops a series of problems that have emerged in practice based on specific CPA

regulations and oral litigation techniques. In view of the influence that the CPA has had on Chile's civil justice reform, the author offers a brief review of the country's 2009 Civil Procedure Code project, noting how it overcomes some of the problems observed in the CPA while presenting others which, in the author's opinion, could influence the implementation and development of the civil procedure reform in Chile. Finally, the study includes specific proposals for correcting problems observed with the CPA. As the author notes, the purpose of this publication is to contribute to the discussion of civil procedure reform, noting the importance of both good and bad experiences presented in other oral procedure systems, including Chile's criminal procedure reform, given the distance that may sometimes lie between theory and practice.

Palabras Clave

Proceso Civil, Reforma Procesal Civil, Litigación Procesal Civil

KEYWORDS

Civil Procedure, Civil Procedure Reform, Civil Procedure Litigation

\section{INTRODUCCIÓN}

La Ley de Enjuiciamiento Civil de España ${ }^{1}$ (en adelante LEC) data del 07 de enero del año 2000. Esta ley sustituyó a la antigua Ley de Enjuiciamiento Civil vigente desde el 03 de febrero del año 1881. Esta última fue objeto de una serie de modificaciones legales durante el tiempo y ya desde los años noventa comenzó un proceso de reforma que involucró a distintos actores, incluyendo el Consejo General del Poder Judicial. En el año 1997, a instancias de este último organismo, se publicó el Libro Blanco de la Justicia el cual efectuaba un balance categórico respecto al lamentable estado de la justicia civil española. Según este libro, eran diversos los problemas presentados por la jurisdicción civil, entre estos la dilación y el atraso del sistema.

"(L)a mala situación de la jurisdicción civil no solo tiene su causa próxima en factores procesales, con ser estos muy importantes, ni puede achacarse exclusivamente a la desorganización de la oficina judicial, ni a la carga de trabajo que soportan los órganos judiciales de este orden jurisdiccional, ni a la falta de

${ }^{1}$ Ley No 1/2000, de 7 de enero, de Enjuiciamiento Civil, (BOE No 7, de 8.1.2000). 
medios materiales o personales, ni a la formación de los integrantes de la oficina, ni a la inexistencia de un sistema ordenado de tramitación de procesos o de una herramienta informática adecuada, ni a la indebida estructura retributiva de sus integrantes, ni a un sistema de ejecución procesal contrario a las reglas mínimas de eficiencia. Tiene su causa, con mayor o menor incidencia, en todos estos factores, normalmente unidos...". ${ }^{2}$ Como señala Gutiérrez-Alviz, "síndrome de fallo múltiple del sistema" era la expresión utilizada por el Consejo General del Poder Judicial en el Libro Blanco y que resumía acertadamente el sentir de sus miembros, compartido por la comunidad jurídica. ${ }^{3}$

Con el objetivo entonces de disminuir la escrituración, reducir los plazos de tramitación, simplificar el proceso, entre otros, la reforma materializada en la LEC estableció un sistema procesal basado en los principios de inmediación, oralidad, publicidad y contradictoriedad, incorporando, por tanto, entre otros cambios, un sistema de producción de información basado audiencias orales. Estas mismas ideas y objetivos han orientado también otros procesos de reforma a la justicia civil, como sucede, por ejemplo, en América Latina. Pero tanto en el sistema español como en otros procesos civiles reformados, la introducción al proceso de estos principios no sólo ha buscado disminuir tiempos de tramitación y hacer más eficiente el sistema procesal sino que también ha pretendido mejorar la calidad de la información que se produce y la calidad de las decisiones judiciales, abandonando así "las formulas inquisitivas tradicionales"

Al día de hoy, a diez años de entrada en vigencia de la LEC, las audiencias orales son el centro del sistema de justicia civil español. Y en estas audiencias la oralidad se ha consolidado de tal manera que ha permitido que otros principios del proceso como la inmediación, en mayor o menor medida, se materialicen de forma efectiva. Lo anterior, que en principio puede parecer obvio, no deja de ser importante de destacar ya que no siempre las experiencias de cambio de sistemas procesales escriturados a otros nuevos orales, a pesar de las reformas legales, han logrado en la práctica consolidar adecuadamente este cambio. ${ }^{5}$ De

\footnotetext{
${ }^{2}$ Consejo General del Poder Judicial, Libro Blanco de la Justicia, Madrid, 1997, p. 151. Citado por Faustino Gutiérrez-Alviz, en "Una nueva Ley de Enjuiciamiento Civil para una mejor Justicia", en GutiérRez-Alviz, Faustino (Dir.), Exposición de la nueva Ley de Enjuiciamiento Civil, Ed. Tirant lo Blanch, Valencia, 2001, p. 20 [cit: "Exposición..."].

${ }^{3}$ Gutiérrez-Alviz, Exposición..., p. 20.

${ }^{4}$ DuCE, Mauricio; Marín, Felipe; RıeGo, Cristián, "Reforma a los procesos civiles orales: consideraciones desde el debido proceso y calidad de la información", en Justicia Civil: Perspectivas para una reforma en América Latina, Ed. Centro de Estudios de Justicia de las Américas, Santiago de Chile, 2008, p. 15. [cit: "Reforma a los procesos..."].

${ }^{5} \mathrm{Al}$ respecto, pueden verse los Informes Comparativos del Proyecto de Seguimiento de las Reformas Procesales Penales en América Latina realizados por el Centro de Estudios de Justicia de las Américas, disponibles en [visita www.cejamericas.org .
} 
ahí que la consolidación de este cambio, no sólo en lo jurídico sino que en la práctica, se transforme en un tema central para las reformas procesales civiles que buscan pasar de un sistema escriturado a uno oral.

En España, aun cuando se mantiene la escrituración en los antecedentes del tribunal, básicamente como una carpeta física que contiene los escritos de las partes, las solicitudes, las resoluciones, etc. -lo cual por cierto no se pone en cuestión-, las actuaciones esenciales del proceso, como, por ejemplo, la rendición de la prueba y la posibilidad de contradecir la misma se efectúa en el juicio oral, ante el juez, no siendo sustituidas estas audiencias por una mera lectura de las actuaciones que constan en el expediente. Otros objetivos de la reforma también se han cumplido. Por ejemplo, los plazos de tramitación se han reducido y el promedio de duración de los casos civiles en primera instancia es de 7.3 meses $^{6}$. Pero una vez instalado el sistema y cumplidos en lo esencial aquellos objetivos principales o de más difícil consolidación, es posible actualmente observar nuevos problemas que afectan o pueden poner en riesgo la efectiva consolidación de estos principios que establece la LEC y la calidad de la información que el sistema genera. A estos problemas se pretende dedicar este trabajo.

Por ejemplo, el establecimiento de un plazo legal generalmente excesivo para la dictación de la sentencia y la falta de sanción por el incumplimiento de este plazo han generado que, en la práctica, las sentencias no se dicten dentro de plazo y éste incluso pueda superar los meses desde que transcurrió el juicio. Como se indicará en este trabajo, dicha regulación, en la práctica, atenta directamente contra la inmediación, toda vez que resulta impensable que un juez que dicte la sentencia meses después del juicio lo haga con un fresco recuerdo de la información producida en juicio debiendo necesariamente recurrir a los escritos y/o sus registros y notas personales para dictar el fallo. La falta de sanción y la imposibilidad legal de dictar el veredicto inmediatamente una vez terminado el juicio se constituyen en incentivos perversos contra la imparcialidad que parece necesario corregir, como propondrá este autor, mediante la incorporación legal de la obligación de dictar un veredicto una vez realizado el juicio, so pena de nulidad, en la forma que se expondrá más adelante.

Otros problemas observados por este autor, y que se desarrollarán durante este trabajo, son, por ejemplo, la contradicción existente entre la imparcialidad objetiva del juez y la norma que permite al mismo manifestar la insuficiencia probatoria y proponer prueba durante la audiencia previa, o la contradicción entre la imparcialidad y la obligación legal del juez de efectuar preguntas ini-

6Promedio obtenido del Informe "La Justicia Dato a Dato. Año 2009" del Consejo General del Poder Judicial, p. 83. Disponible en www.poderjudicial.es . 
ciales al testigo sobre su vinculación e intereses. En la práctica, por ejemplo, la primera de estas contradicciones planteadas hace que, como regla general, los jueces no utilicen dicha facultad precisamente porque son conscientes del riesgo existente para su imparcialidad. En este caso, este autor propondrá eliminar esta posibilidad y permitir al juez dictar un fallo que ponga término al caso por este motivo.

Todos estos problemas afectan principios elementales del proceso, del debido proceso, como son la inmediación, la contradicción o la imparcialidad. De lo anterior pueden derivarse no sólo consecuencias jurídicas sino que, en la práctica -lo que es el objeto de este trabajo- se disminuye la calidad de la información y la calidad de las decisiones jurídicas que podrían obtenerse a partir de un sistema procesal con centro en el juicio oral. De cierta forma, los problemas que se expondrán vinculan a los tres principios afectados, si bien en ocasiones afectan también a otros principios. Podría tratarse entonces de temas de segunda o tercera generación, considerando que la implementación del sistema, en sí mismo, ha resultado exitosa.

Un hecho que a juicio de este autor agrava o se encuentra en directa relación con estos problemas y que está jugando en contra de la producción de información de mejor calidad es la carencia en España de programas de técnicas o destrezas de litigación en audiencias orales. A pesar del tiempo que lleva vigente la LEC y de la tendencia a la oralización de los procesos, el día de hoy es prácticamente nula la oferta de programas en pre y post grado que aborden este tipo de destrezas. A este punto se dedicarán también unas líneas de este trabajo.

Los problemas que se plantean en el presente trabajo surgen al autor principalmente a partir de la observación presencial de múltiples audiencias de procesos declarativos civiles en los Juzgados y Tribunales de Barcelona y su provincia: juicios verbales, audiencias previas y juicios orales del procedimiento ordinario. Se basan también en entrevistas sostenidas por el autor con jueces, abogados y procuradores, incluyendo actores que participaron en algunas de las audiencias observadas. Se nutren las observaciones además del análisis de parte de la doctrina y jurisprudencia en relación a los temas relacionados, en donde el autor ha podido constatar, generalmente con posterioridad a la observación, que muchos de los problemas ya habían sido observados o constatados, pero generalmente abordados desde una perspectiva teórica. Y, por cierto, se nutren de la experiencia práctica y teórica de este autor en materia de litigación en sistemas procesales orales.

Debe aclararse que el presente trabajo, atendida su extensión y finalidad, no ha utilizado un estricto sistema metodológico estadístico ni una sistematización acabada de las entrevistas, propio quizás de una investigación de doctorado u otro tipo de estudios, por lo que no pretende ser un referente en cuanto a cifras o porcentajes sino sólo un reflejo de las observaciones y opiniones de este autor. En este sentido, más bien se ha utilizado en parte una metodología descriptiva, 
no obstante lo cual se ha pretendido contrastar las observaciones y problemas detectados con las entrevistas, el análisis de doctrina y la jurisprudencia, según sea el caso. A su vez, producto de las razones antes indicadas, el presente trabajo se ha centrado sólo en los procesos declarativos y no se refiere a otros procedimientos contenidos en la LEC o en otras leyes especiales.

Sin duda, pueden y deben existir otros problemas que no han sido observados, pero los mencionados en este trabajo parecen fundamentales a este autor a la hora de pensar en la implementación o consolidación de un sistema procesal civil que efectivamente pretenda ser oral más allá de los cambios legislativos y obtener todas las ventajas que ofrece en la práctica un modelo oral. En este sentido, conviene poner en conocimiento del lector que en América Latina, y particularmente en Chile, país de este autor, actualmente hay un proceso de reforma procesal civil al cual se pretende aportar ciertas observaciones a tener en cuenta a la hora de implementar con éxito un nuevo sistema procesal civil.

De esta forma, el presente trabajo se compone de las siguientes partes. En primer lugar, se entregarán algunas cifras referenciales respecto al estado de la justicia civil en España principalmente en primera instancia. Lo anterior, con el objeto de contextualizar al lector en la lectura de algunos de los problemas que se plantean durante este trabajo. Con el mismo objeto, se mencionan algunas propuestas específicas de mejoras elaboradas por destacados académicos. En segundo lugar, se efectuará una descripción de las principales etapas del proceso y de la observación de audiencias efectuadas por el autor. En las mismas se incluirán algunos puntos u opiniones surgidas de las entrevistas realizadas. En tercer lugar, se plantearán los problemas observados y se abordarán desde la doctrina y/o jurisprudencia, pero esencialmente desde sus efectos prácticos. En cuarto lugar, se realizará una breve referencia al proyecto de Código Procesal Civil de Chile a partir de los problemas abordados en el trabajo con el objeto de verificar si éstos podrían o no presentarse en el proyecto chileno. Finalmente, se presentarán algunas propuestas de modificación o sugerencias a considerar en los procesos de reforma.

El modelo español vigente desde 2001 se ha erigido en uno de los modelos a seguir en los procesos de reforma en América Latina, de ahí la importancia de analizar estos temas no sólo desde el plano legal sino también desde un enfoque práctico. Se espera, asimismo, contribuir en lo posible al debate sobre el estado de la justicia civil en España, proceso que se encuentra en permanente análisis y con proyectos de modificación para los próximos años, con el objeto de mejorar la eficiencia del mismo, alguno de los cuales serán mencionados en el presente trabajo. Por último, y si bien no es el objeto de este trabajo, cabe hacer presente que muchos de los temas que serán abordados probablemente serán de gran trascendencia a la hora de discutir y de que entre en vigencia la reforma a la Ley de Enjuiciamiento Criminal española que fue presentada hace pocas semanas 
por el Ejecutivo, cuya lógica de funcionamiento con una marcada separación de funciones entre investigador y juzgador, audiencias ante un juez de garantías y luego un juicio oral, pondrán de relieve la importancia de contar con las mejores herramientas y prácticas para la producción de información de calidad.

\section{Algunos anteCedentes sobre el estado actual del SISTEMA DE JUSTICIA CIVIL ESPAÑOL}

Según las estimaciones hechas en el Informe Avance 2010 del Consejo General del Poder Judicial, el año 2010 ingresaron en materia civil un total de 2.049.416 causas. En ese mismo año fueron resueltas 1.948.012 causas. Quedaron pendientes en materia civil 1.431.029 causas a fin del año 2010. Respecto a esta última cifra destaca que ella representa prácticamente la mitad de todas las causas pendientes en el sistema de justicia que terminó el año 2010 con 3.274.762 causa pendientes, superando a las otras jurisdicciones. ${ }^{7}$ En el año 2009 en tanto ingresaron en materia civil 2.025.568 causas, siendo resueltas 1.746.326 causas y quedando en trámite 1.329 .625 causas, siendo, al igual que en el año 2010, la jurisdicción con mayor causas pendientes. ${ }^{8}$ Cabe señalar, a modo ejemplar, que en el año 2003 ingresaron 1.138 .744 causas y en el 2004 1.196.498 causas $^{9}$, prácticamente doblando el número de ingresos en 7 años.

Para los autores del Informe "Reformas necesarias para potenciar el crecimiento de la economía española" publicado en 2011, en relación a las modificaciones necesarias para mejorar la eficiencia del sistema de justicia español, el incremento de causas civiles al año 2010 podría deberse, entre otras circunstancias, al aumento de causas en juicio monitorio producto de la crisis económica y a la tramitación preferente que se da a las causas penales por sobre los civiles en los 1065 juzgados mixtos (de Instrucción Penal y de Primera Instancia) existentes. ${ }^{10}$ Según el mismo Informe "(e)I retraso en la resolución de

\footnotetext{
${ }^{7}$ La justicia penal terminó con 1.174 .531 causas pendientes, la contencioso-administrativa con 367.020 causas, la social con 302.100 y la militar con 82 causas. Cifras obtenidas del informe "Avance 2010" del Consejo General del Poder Judicial. Disponible en www.poderjudicial.es.

${ }^{8}$ Cifras obtenidas del Informe "La Justicia Dato a Dato. Año 2009" del Consejo General del Poder Judicial. Disponible en www.poderjudicial.es.

${ }^{9}$ Cifras obtenidas del Informe Final del Estudio "Levantamiento de información y análisis de modelos orgánicos comparados", Vol. 1., elaborado por el Centro de Estudios y Asistencia Legislativa (CEAL) de la Pontificia Universidad Católica de Valparaíso de Chile en abril de 2006, p. 46, quienes citan como fuente la Memoria del Consejo General del Poder Judicial de España. Disponible en: http://web.minjusticia.cl/ucrpc/estudios/eyd_modelos_comparativos.pdf [cit: "Levantamiento..".].

${ }^{10}$ Salvador Coderch., Pablo y otros, "Reformas necesarias para potenciar el crecimiento de la economía española", Vol. I: Justicia, Financiación autonómica y Sanidad, Ed. Civitas, Navarra, 2011, pp. 27 y 28. [cit: "Reformas necesarias..."].
} 
los conflictos sigue siendo, pues, el problema principal de la Justicia española, el primero que hay que abordar y solucionar". ${ }^{11}$ Este mismo estudio efectúa una serie de propuestas para reducir la tasa de congestión en la jurisdicción civil y reforzar el principio de oralidad. Las propuestas que se citan textualmente del estudio son ${ }^{12}$ :

1) "Incrementar la cuantía de los juicios verbales, actualmente fijada en $6.000 €$ (art. 250.2 LEC) hasta $25.000 €$ o, incluso, hasta $50.000 €$ ".

2) "(I)ncrementar la cuantía del procedimiento monitorio, en la actualidad limitada a $250.000 €$ (art. 812.1 LEC), hasta $500.000 €$, así como limitar drásticamente la de desviar el asunto al juicio ordinario que corresponda por el simple procedimiento de presentar un escrito de oposición (art. 818 LEC)".

3) "Potenciar la posibilidad de dictar sentencia verbalmente en los asuntos sencillos, de Justicia de base".

4) "Incrementar la cuantía de los juicios que no requerirían defensa de abogado y representación de procurador hasta los $1.500 €$ en todo caso, o incluso hasta los $3.000 €$ con la condición de que la parte facilitara previamente al secretario judicial una dirección de correo electrónico a efectos de notificaciones y comunicaciones".

5) "Introducir modificaciones en el sistema de recursos, tales como tender a la supresión del recurso de reposición, reservándolo para la impugnación de errores materiales manifiestos aunque manteniendo siempre la exigencia de la protesta en el acto. En cuanto al recurso de apelación, planteamos dos posibilidades: (a) exigir un aval que cubriera los gastos del proceso, o bien y menos drásticamente (b), establecer una tasa especial fija pero disuasoria para determinadas apelaciones".

6) "Atribuir en exclusiva las competencias de ejecución a los Secretarios Judiciales, a quienes además habría que corresponder la gestión de las ejecuciones".

7) "Suspender la ejecución de una sentencia en caso de apelación, sólo si aquella hubiera probabilidad razonable de causar un perjuicio irreparable o si el apelante presentara aval o garantía equivalente, por cantidad igual, por lo menos, al 125\% del objeto de la condena".

8) "Desjudicializar los procedimientos de jurisdicción voluntaria".

Otro de los asuntos en actual discusión es la reforma de la Ley de Planta Judicial que permita dividir entre jueces de base y jueces de instancia, modificando a su vez las competencias y funciones de la nueva oficina judicial administrativa común. Medidas como las propuestas en dicho informe no sólo

${ }^{11}$ Salvador y otros, "Reformas necesarias...", p. 28.

${ }^{12}$ Salvador y otros, "Reformas necesarias...", pp. 31 a 34. 
tienden a modernizar el sistema de justicia sino también a agilizar la tramitación de causas y disminuir el retraso judicial. Según el Informe de la Comisión sobre Demarcación y Planta "(u)na Ley de Planta acorde al nuevo contexto de administración de justicia exige trasladar el actual sistema de organización colegiada de los órganos superiores a los órganos de base y primera instancia. De este modo, el conjunto de jueces de base o de jueces de instancia de una misma demarcación pueden constituir un único tribunal con un presidente y con una oficina que presta servicio a todos ellos".$^{13}$ Esta oficina administrativa común permitiría liberar a los jueces de una serie de funciones sobre las que deben estar pendientes por tratarse de tribunales unipersonales. ${ }^{14}$

En materia de duración de las causas civiles, como se señaló en la introducción, la duración promedio de un caso en primera instancia es de 7.3 meses. En las Audiencias Provinciales las causas civiles duran, en recurso 5.5 meses y en única instancia 3.9 meses..$^{15}$ Cabe señalar que en el año 2003 la duración promedio en primera instancia era de 9.72 meses y el 200410.54 meses. $^{16}$

De todo lo anterior es posible inferir que en el sistema de justicia civil ingresan más casos año a año, que el nivel de casos que se resuelven es menor y que aun cuando los plazos han mejorado considerablemente en relación al modelo anterior a la LEC, es necesario estar en permanente análisis y revisión del sistema con el fin de evitar que éste se termine desnaturalizando de sus intenciones iniciales.

\section{Observación de audiencias en la Ciudad de la Justicia de Barcelona. BREVE DESCRIPCIÓN DE LA VISITA}

Como se señaló al inicio de este trabajo, los problemas observados y que serán abordados en el próximo capítulo surgen en gran parte de la observación de audiencias efectuadas por el autor junto con las entrevistas realiza-

\footnotetext{
${ }^{13}$ Comisión de Demarcación y Planta, "Informe de la Comisión sobre Demarcación y Planta", Ministerio de Justicia de España, Madrid, 2010, p. 8. Disponible en www.mjusticia.es

${ }^{14}$ Existen experiencias similares en el sistema comparado. Por ejemplo, en Chile la justicia penal incluye la figura de los juzgados de Garantía y Tribunales Orales en lo Penal. En lo que importa en este punto es posible decir que la organización de dichos tribunales no responden a la concepción de un juez titular de su tribunal sino que un Juzgado de Garantía tiene un número variado de jueces, que son presididos por un presidente y, además, se contempla la figura del Administrador del Tribunal, a cargo de las funciones y equipo administrativo. Sobre la organización de la estructura judicial y administrativa en materia penal chilena y sobre otros temas de modernización judicial puede consultarse, entre otros, Revista Sistemas Judiciales N5 "Gestión Judicial y Administración de Tribunales". Julio de 2005. Ed. Centro de Estudios de Justicia de las Américas. Disponible en www.cejamericas.org o www.sistemasjudiciales.org.

${ }^{15}$ Cifras obtenidas del Informe "La Justicia Dato a Dato. Año 2009" del Consejo General del Poder Judicial, p. 83.

${ }^{16}$ CEAL, "Levantamiento...", p. 51.
} 
das. A continuación se efectúa entonces una descripción de las principales audiencias observadas y luego se realizan algunos comentarios para cada una de ellas.

\section{La Audiencia Previa}

Esta audiencia resulta central en el proceso. Conforme al art. 414 de la LEC, esta audiencia tiene por objeto intentar un acuerdo o transacción entre las partes, fijar los hechos controvertidos y los medios de prueba que serán presentados en la audiencia de juicio. Asimismo, en esta se resuelven las cuestiones procesales que pudieran obstar a la prosecución del juicio, por ejemplo, la cosa juzgada o falta de capacidad, y se solicita la exclusión de pruebas.

De acuerdo al art. 428 de la LEC, el tribunal podrá exhortar a las partes a que lleguen a un acuerdo y, en caso de que no haya acuerdo, pero estuvieren conformes a los hechos y sólo hubiese disputa jurídica el tribunal tiene la posibilidad de dictar sentencia inmediata. El art. 429 de la LEC, otorga al juez la posibilidad de sugerir la realización de pruebas en el caso de que considere que las pruebas presentadas por las partes son insuficientes. Aun cuando no sugieran pruebas, sí puede poner de manifiesto la insuficiencia probatoria para que las partes puedan modificar o completar sus proposiciones de prueba.

En cuanto a la exclusión de prueba, la norma general estaría dada por el art. 283, referente a la impertinencia o inutilidad de la actividad probatoria, en el cual establece los casos en que no debe admitirse una prueba. Estos casos son: a) no guardar relación con el objeto del proceso; b) las inútiles, aquellas que según reglas y criterios razonables y seguros no puedan contribuir a esclarecer los hechos, y c) aquellas que provengan de actividades prohibidas por la ley. Lo anterior guarda relación con el art. 429.2 el cual indica que una vez admitidas las pruebas pertinentes y útiles se fijará la fecha de juicio. Conforme al art. 247, es posible cuestionar la autenticidad de los documentos presentados por la contraparte, pudiendo proponerse prueba sobre ella. Destaca también el art. 287, el cual se refiere a la ilicitud de la prueba. De acuerdo a este artículo, si una parte estima que un medio de prueba proviene o es fruto de una actividad que ha vulnerado derechos fundamentales debe alegarlo de inmediato. Ello también puede ser suscitado de oficio por el tribunal. Conforme al art. 287, esta alegación se resolverá en el acto de juicio, no en la audiencia previa. El art. 299 define cuáles son los medios de prueba que pueden hacerse valer en juicio. Éstos son: el interrogatorio de las partes, documentos públicos y privados, dictamen de peritos, reconocimiento judicial y testigos. El art. 299 también señala unas cláusulas amplias de aceptación como medios probatorios de archivos o medios de reproducción audiovisuales y una cláusula genérica de cualquier medio no previsto del cual pueda obtenerse certeza sobre hechos relevantes. 
De no existir acuerdo, o bien, la discrepancia sobre los hechos y el derecho se mantenga, y habiéndose admitido las pruebas pertinentes y útiles, el juez procederá a señalar la fecha de juicio el cual, conforme al art. 429.2, deberá celebrarse en el plazo de un mes desde terminada la audiencia.

\subsection{Comentarios de la observación de audiencias previas}

Tal como se indicó, esta audiencia tiene un rol fundamental en los juicios ordinarios toda vez que es en esta audiencia en donde se definen los hechos controvertidos y las pruebas que serán presentadas en juicio. Según manifiesta una jueza consultada, previo a esta audiencia, ella revisa los antecedentes para saber de qué trata el caso, para mantener un respeto con las partes y evitar dilaciones innecesarias, pero se desconoce si eso es una práctica generalizada y cuál es la profundidad de dicha revisión, cuánto tiempo se destina a ella, etc. El juez adquiere un rol central como moderador de los tiempos y, en general, se nota en los magistrados una preocupación porque los asuntos y las discusiones vayan al meollo. Así, no parece haber mucho espacio para discusiones teóricas innecesarias o dilatorias, siendo poco tolerantes los jueces a sacrificar su tiempo. En este sentido, las audiencias por lo general son bien concretas y no se aprecian mayores debates jurídicos de fondo sobre el asunto. Detrás de estas observaciones queda claro que los jueces son consientes de la alta carga de trabajo y del valor de su tiempo. También da cuenta de un sistema consolidado, que puede funcionar con un ritmo adecuado a una alta carga laboral, pero también da cuenta de cierta rutinización en las prácticas. Pareciera ser que en la medida que los actores conocen los criterios de uno u otro magistrado y son consientes de la valoración del tiempo tanto para los jueces como para ellos mismos, se evita entrar en confrontaciones a veces innecesarias, pero a veces posiblemente necesarias, como puede ser la pertinencia o utilidad de un medio probatorio.

En este sentido, si bien es en esta audiencia en la cual las partes definen cuáles serán sus pruebas, y las pruebas de la contraparte, en general no se observan mayores objeciones a las pruebas de la contraparte. Los jueces parecen más activos a la hora de limitar la prueba. Una vez excluida una prueba la parte puede presentar un recurso de reposición a la decisión del tribunal. En la práctica, la reposición parece tener poca incidencia en poder revertir la resolución de exclusión y principalmente sirve para preparar posteriores recursos.

Respecto a la prueba testimonial, no se aprecia que las partes en la audiencia aborden el contenido específico de cada declaración ni se profundice demasiado en el fondo de la misma. Lo anterior tiene relevancia ya que, como incluso manifestaron algunos jueces consultados, ellos no conocen del testimonio hasta el juicio, lo cual dificulta que puedan formarse una impresión mayor que ponga en juego su imparcialidad objetiva. Parece existir opinión unánime en los 
jueces consultados de que, hasta el juicio, ellos si bien tienen lógicamente una idea del caso con los antecedentes presentados, esa idea no necesariamente se traduce en un prejuzgamiento del caso. Puede suceder que en esos escritos ya se pueda apreciar la solidez de una postura pero no es extraño que esta pudiese variar en el juicio.

En cuanto a las facultades previstas en el art. 429 de la LEC, de las audiencias observadas no se apreció a ningún juez sugiriendo prueba ni posibles acuerdos a las partes, estando prevista esta posibilidad por ley. En cuanto a los acuerdos, ello puede deberse al desconocimiento previo y natural de los jueces respecto al caso, conforme al volumen de trabajo, lo que les impide proponer buenos acuerdos; o a la idea de que son las propias partes las más interesadas en llegar a este y, si no lo han hecho previamente, difícilmente podrán en unos minutos llegar a un acuerdo propuesto por el juez. En este sentido, esta facultad parece más un rito o una formalidad que una atribución con efectos concretos en la práctica, si bien esto podría variar con la implementación de la Directiva 2008/52/CE del parlamento europeo y del consejo de 21 de mayo de 2008 sobre ciertos aspectos de la mediación en asuntos civiles. Respecto a la posibilidad de manifestar la insuficiencia de prueba y proponer medios, como se analizará posteriormente, en general los jueces entrevistados estiman que dicha facultad puede poner en riesgo su imparcialidad frente al caso.

En cuanto a la fijación de la fecha para la realización del juicio, los tribunales manejan su propia agenda y, por lo general, los juicios no se fijan dentro del plazo de 30 días establecido en la ley.

Por último, cabe señalar que la audiencia se desarrolla completamente de forma oral, el juez está presente durante toda la audiencia y que la audiencia es efectivamente pública. Tanto las partes como el juez cuentan durante la audiencia con la carpeta judicial y van consultando la misma en diversas oportunidades, pero ello no significa que la audiencia se transforme en una lectura de la misma.

\section{Audiencia de Juicio Ordinario}

Esta audiencia tiene por objeto presentar ante el juez los medios probatorios, efectuar las alegaciones y presentar las conclusiones orales respecto a los mismos y, en definitiva, que el juez pueda conocer de estos para emitir una sentencia. La audiencia se rige por los principios de oralidad, inmediación y contradicción.

Respecto al interrogatorio de las partes, los art. 301 y siguientes dan las pautas para ello. Cabe señalar que la LEC distingue entre el testimonio de las partes y el de los testigos, cuya declaración está regulada en los arts. 360 y siguientes. Según el art. 302, las preguntas a las partes deben realizarse oralmente en sentido afirmativo, con claridad y precisión. Asimismo, señala que las preguntas no deberán incluir valoraciones ni calificaciones y si éstas se incorporan se tendrán por no realizadas. El art. 303 incorpora una norma que permite objetar 
las preguntas. La impugnación a que se refiere el art. 303 permite impugnar la admisibilidad de las preguntas haciendo notar las valoraciones y calificaciones que contenga la pregunta y que se estimen improcedentes. Destaca la facultad del art. 307 que permite al tribunal en caso de negativa de una parte a declarar, dar por ciertos los hechos preguntados que no sean respondidos, salvo que exista una obligación legal de silencio. El art. 310 prevé la situación en que vayan a declarar dos o más partes sobre los hechos controvertidos indicando que se adoptaran medidas para evitar que puedan comunicarse y conocer previamente las preguntas y respuestas. La valoración de la declaración de partes se rige por dos reglas: la de la sana crítica y la de valoración legal, esta ultima dada por lo establecido en el art. 316, el cual señala que se tendrán por ciertos los hechos que reconozca una parte si intervino personalmente, éstos le perjudican y no contradice otras pruebas.

En cuanto a los testigos, el art. 361 establece que todas las personas podrán ser testigos salvo los privados de razón, los privados de sentido (si el juicio tiene que ver con ello) y los menores de 14 años que no tengan el discernimiento necesario a juicio del tribunal. En cuanto a su separación y forma de interrogatorio se asimilan a las partes. Destaca el art. 367 que contiene un listado de preguntas que debe hacer el juez antes de la declaración. Entre estas preguntas se encuentran además de su identificación, si tienen vinculación a alguna de las partes, si está al servicio de alguna de ellas, si tiene interés directo o indirecto, si hay amistad o enemistad, si ha sido condenado por falso testimonio, etc. Esta norma permite al tribunal interrogar al testigo sobre todo ello y permite a las partes manifestar problemas de imparcialidad del testigo. El art. 373 permite al tribunal de oficio o a petición de parte acordar un careo cuando los testigos incurran en graves contradicciones. Aun cuando el art. 361 establece la idoneidad para ser testigo destaca el hecho que conforme al art. 377 existen las tachas de testigos. También existe respecto a los peritos. El art. 376 establece el valor probatorio de la declaración de testigo, señalando que se regirá por la sana crítica.

\subsection{Comentarios de la observación de audiencias de juicio ordinario}

Cabe señalar, en primer lugar, que, al igual que la audiencia previa, la audiencia de juicio es efectivamente pública y se desarrolla de forma oral. Las audiencias se desarrollan de forma dinámica, no hay mayores ritualismos, ni espacios para latas alegaciones. Se nota tanto en tribunales como en los litigantes, una dinámica adquirida de los juicios.

De los casos observados fue prácticamente nula la discusión a cabalidad respecto a derecho, sino más bien se trató de discusiones fácticas. Los alegatos finales de los abogados son breves, en pocas ocasiones hacen mención a palabras de los testigos y sus posiciones, por lo que no parecieran obtener mayor información de los testigos para incorporar en sus conclusiones. 
En relación al interrogatorio de los testigos, en las audiencias observadas no se vio en general que los jueces hicieran preguntas a los mismos más allá de las preguntas iniciales. Sólo en una de ellas se apreció una mayor proactividad del juez en realizar preguntas que iban por sobre un sentido aclaratorio. En cuanto a los actores, Ilama la atención los defectos de litigación en cuanto a la forma de interrogar -no a que no sean orales las audiencias- considerando el tiempo de implementación del modelo y cómo se mueve la máquina de tribunal. No se observaron objeciones a las preguntas efectuadas por los abogados a pesar de que la mayoría de las preguntas efectuadas por la parte que presentaba al testigo eran de carácter sugestivo, o bien preguntas compuestas.

Respecto al interrogatorio cruzado, por lo general eran muy breves y se limitaban en ocasiones a reiterar información que ya había sido entregada por el testigo. Esto último hacía que en ocasiones el juez fuese muy activo en indicar a la parte que preguntase algo que no fuese conocido por el tribunal. Frente a estas advertencias, los abogados por lo general no manifestaban reparos al juez en torno al punto o información que pretendían obtener mediante sus preguntas, si esto los llevaría a una conclusión distinta, etc. Al igual que en el interrogatorio inicial, se aprecia en el examen cruzado un uso importante de preguntas compuestas y sugestivas. En relación a estas últimas, si bien a juicio de este autor son las preguntas propias de un examen cruzado, no pareciera que las mismas se utilicen con el objeto de obtener una mejor información del testigo para que quede en conocimiento del tribunal sino más bien como un defecto de litigación. Por último, cabe señalar que no se apreció en ningún interrogatorio ni contrainterrogatorio que se hiciesen preguntas de acreditación o desacreditación del testigo o del testimonio, pareciendo conformarse las partes con las preguntas iniciales que realiza el juez casi de forma ritual.

En relación a la prueba documental, los documentos en general no son objeto de discusión durante el juicio, al parecer son incorporados y no objetados, y ya quedará a criterio del tribunal como los evalúa. Algunos de estos son exhibidos a los testigos. Asimismo, en los juicios no se observó el uso de prueba audiovisual, ni la exhibición de fotos, etc.

Aun cuando el juez que conoce el juicio es el mismo juez que ha llevado el proceso desde el inicio, no se aprecia que los jueces vengan con algún prejuzgamiento sobre el caso ni se nota una actitud displicente con el mismo, quizás el volumen de trabajo es una de las razones que finalmente evita ello.

\section{Audiencia de Juicio Verbal}

El art. 250 de la LEC establece el ámbito de aplicación del Juicio Verbal. La principal diferencia está dada por la cuantía y por la concentración en una sola audiencia de las actuaciones principales que en el juicio ordinario se efectúan en la audiencia previa y en el juicio oral. Bajo los 6.000 euros corresponde al 
juez conocer bajo las reglas de este proceso contempladas en el Título III del Libro II, artículos 437 a 447 de la LEC.

Al juicio verbal se da inicio mediante una demanda sucinta que contenga los datos de identificación del demandante y el demandado y una exposición de lo pedido. Luego del examen de la demanda por el Secretario Judicial, si ésta es admitida, se cita a las partes a la celebración de una vista, lo cual debe ocurrir entre 10 y 20 días desde la citación. La vista se efectúa en una audiencia oral y pública en la cual demandante y demandado exponen sus fundamentos. Luego de ello, el tribunal resuelve y decide si manda a proseguir el juicio. En su caso, se fijan los hechos y, si no hay conformidad sobre ellos, se recibe inmediatamente la causa a prueba. Las pruebas se proponen en la misma audiencia, en donde también se debate sobre su pertinencia y utilidad. Al igual que en la audiencia previa del juicio ordinario, si el juez estima que la prueba es insuficiente puede indicarlo a las partes y proponer prueba. Practicadas las pruebas se da por terminada la vista y el tribunal debe dictar sentencia dentro de 10 días.

Más allá de ciertas reglas especiales que se dan en el juicio verbal, lo cierto es que la misma concentra en una sola audiencia las audiencias previas y de juicio oral toda vez que el legislador ha buscado mediante esta figura dar celeridad y rapidez a los pleitos de menor cuantía. Como se señaló anteriormente, actualmente existen propuestas para aumentar la cuantía de este tipo de audiencias, permitiendo de esta forma disminuir la realización de una serie de trámites y audiencias que pueden ventilarse en un solo acto y reducir con ello los tiempos de tramitación en materia civil.

\subsection{Comentarios de la observación de juicios verbales}

Al igual que las audiencias previas y de juicio ordinario, las vistas del juicio verbal son efectivamente orales y no hay lectura por los intervinientes. Tampoco se hace una lectura de la demanda ni de la contestación.

En general, gran parte de las observaciones hechas en relación a las otras audiencias observadas se reproducen en esta audiencia. Entre los puntos que quisiera agregar es que en una de las audiencias observadas se preguntó por el magistrado a las partes si estas tenían una hoja con la individualización de las pruebas (hoja con nombres de partes y documentos). Ninguna de las partes las tenía, puesto que las presentan verbalmente. Lo anterior parece demorar la audiencia en tanto toca al juez y a la otra parte escribir que prueban son las que se presentarán. Parecería interesante que las partes presentaran o acompañaran en la misma audiencia un listado con la identificación de las pruebas que se presentaran, tanto al juez como a la contraparte, independientemente del debate y que la presentación verbal sea la principal, atendido el tiempo que se pierde mediante la lectura y anotación manual de los antecedentes. Al 
parecer, esta sí sería una práctica exigida por algunos tribunales, quienes incluso lo solicitan al momento de fijar la audiencia. Esta sencilla práctica permite dar más celeridad a la audiencia.

Atendido que en esta audiencia se ve también la pertinencia de la prueba es posible que testigos que acompañan a las partes a la celebración de la audiencia sean excluidos en la misma y no puedan declarar. Por ejemplo, en un caso, la parte demandada presentó un informe pericial y un perito. La demandante solicitó la exclusión del informe pericial toda vez que el mismo debía acompañarse 5 días antes para garantizar la contradictoriedad. El tribunal accedió a la exclusión pero, sin mayor debate, autorizó la declaración del perito como testigo en tanto vio el lugar y los asuntos en disputa.

Llama la atención que el informe pericial se incluye como tal en el proceso, y se tiene por prueba el informe mismo, además de la declaración del mismo perito. El perito es primero interrogado por la parte que lo ofrece y puede ver el informe mientras declara. Desde el punto de vista de litigación, Ilama la atención que no existe mayor debate acerca de la legitimidad del perito, no se le realizan preguntas de acreditación por quien lo ofrece y tampoco preguntas por la contraparte respecto a la acreditación del mismo. Se aprecian, en este sentido, ciertas deficiencias en materia de litigación oral que, sin duda, podrían contribuir a mejorar la calidad de la información que ingresa al juicio.

\section{Principales problemas observados}

A continuación se expondrán una serie de problemas observados por el autor. Éstos, como se dijo, surgen tanto del análisis de la LEC como de la observación en la práctica de audiencias y de las entrevistas efectuadas. Asimismo, se complementan los mismos con el análisis de doctrina y jurisprudencia que en algunos casos ya ha hecho eco de ellos. Para facilitar su lectura y comprensión se ha intentado presentar los mismos en el orden o etapa procesal en que estos pueden surgir, como si se fuese siguiendo un caso.

\section{Medidas cautelares en el proceso civil e imparcialidad del juez}

Decidir sobre las medidas cautelares, y luego conocer el juicio oral, puede constituir una situación que afecte la imparcialidad objetiva del juez. El legislador español fue consciente de ello y, de hecho, da cuenta de esta situación en el Preámbulo de la Ley de Enjuiciamiento Civil del 2000. Si bien no señala específicamente que existe una vulneración de la imparcialidad objetiva, el contenido del texto nos permite afirmar esta posición. El Preámbulo señala:

"Frente a alguna posición partidaria de atribuir el conocimiento y resolución acerca de las medidas cautelares a un órgano jurisdiccional distinto del competente para el proceso principal, la ley opta por no separar la competencia, sin 
perjuicio de que no implique sumisión, respecto del proceso, la actuación de la parte pasiva en el procedimiento relativo a medidas solicitadas antes de la interposición de la demanda. Esta opción no desconoce el riesgo de que la decisión sobre las medidas cautelares, antes de la demanda o ya en el seno del proceso, genere algunos prejuicios o impresiones a favor o en contra de la posición de una parte, que puedan influir en la sentencia. Pero, además de que ese riesgo existe también al margen de las medidas cautelares, pues el prejuicio podría generarse en la audiencia previa al juicio o tras la lectura de demanda y contestación, esta ley se funda en una doble consideración. Considera la ley, por un lado, que todos los jueces y Magistrados están en condiciones de superar impresiones provisionales para ir atendiendo imparcialmente a las sucesivas pretensiones de las partes y para atenerse, en definitiva, a los hechos probados y al Derecho que haya de aplicarse. Y por otra, no se pierde de vista que las medidas cautelares han de guardar siempre relación con lo que se pretende en el proceso principal e incluso con vicisitudes y circunstancias que pueden variar durante su pendencia, de suerte que es el órgano competente para dicho proceso quien se encuentra en la situación más idónea para resolver, en especial si se tiene en cuenta la posibilidad de alzamiento y modificación de las medidas o de su sustitución por una equitativa contracautela. Todo esto sin contar con la menor complejidad procedimental que comporta no separar la competencia".$^{17}$

Tal como se desprende de las palabras del legislador, éste no desconoce el riesgo existente en la imparcialidad del juez a la hora de decidir si ya se ha pronunciado sobre las medidas cautelares. Expresamente señala que este conocimiento y adopción puede generar ciertos prejuicios o impresiones a favor o en contra de la posición de una parte que pueden influir en la sentencia. La imparcialidad, sabemos, puede ser definida como "la ausencia de prejuicios a favor o en contra de una de las partes o en relación con la materia sobre la cual deben decidir"18. Asimismo, generalmente se ha diferenciado entre imparcialidad subjetiva e imparcialidad objetiva. La imparcialidad subjetiva dice relación con las relaciones personales que puedan vincular al juez con las partes de un proceso. La imparcialidad objetiva en tanto puede ser definida como "la que relaciona al juez o Tribunal con el proceso propiamente dicho y con los prejuicios que su contacto con él (el proceso) puede provocarle en las decisiones que debe adoptar en el seno del procedimiento". ${ }^{19}$

\footnotetext{
${ }^{17}$ Preámbulo, XVIII, Ley № 1/2000 de Enjuiciamiento Civil.

${ }^{18}$ Definición de Julio Maier. En DUCE, Mauricio y RIEGO, Cristian, Proceso Penal, Ed. Jurídica de Chile, 2007, p. 102.

${ }^{19}$ GUERRERO P., Salvador, La imparcialidad objetiva del Juez Penal, Ed. Aranzadi, Navarra, 2009, p. 28. [cit: "La imparcialidad..."].
} 
A pesar de que en general la doctrina y la mayoría de la jurisprudencia ha tratado el principio de la imparcialidad en relación al proceso penal, la imparcialidad es un principio procesal y, por tanto, no es posible excluir su aplicación y consecuencias de su vulneración en el campo civil. Tal como lo ha señalado el Tribunal Constitucional español, el derecho a un juez imparcial es una garantía fundamental de la Administración de Justicia en un Estado de Derecho. ${ }^{20}$ Este mismo tribunal ha entendido que la imparcialidad supone "de un lado, que el juez no pueda asumir procesalmente funciones de parte, $y$, de otro, que no pueda realizar actos ni mantener con las partes relaciones jurídicas o conexiones de hecho que puedan poner de manifiesto o exteriorizar una previa toma de posición anímica a su favor o en su contra". ${ }^{21}$

Llama la atención entonces que, tratándose de una garantía fundamental del debido proceso y reconociéndose el posible prejuicio, pareciera ser el propio legislador quien ha legitimado su vulneración a pesar de que esta garantía pretende precisamente evitar esa posibilidad riesgo de contaminación que incide en la sentencia. ¿Cómo puede ser, entonces que, frente a un reconocimiento explícito del riesgo, no se haya optado por garantizar su protección? ¿Parecen suficientes las explicaciones otorgadas por el legislador para no garantizar dicha medida? Tratándose de la afectación de una garantía del debido proceso hubiese sido exigible al legislador un desarrollo más acabado y extenso del porqué de esta decisión. Sin duda, la lectura de esta parte del preámbulo pareciera contener un germen de inconstitucionalidad que hubiese exigido un mayor desarrollo.

La adopción de medidas cautelares ha sido un supuesto de contaminación recurrente en las sentencias del Tribunal Constitucional. ${ }^{22}$ Por ejemplo, la sentencia 320/1993 de 08 de noviembre, que se refiere a las medidas cautelares reales, medidas propias del proceso civil. Según el Tribunal Constitucional "(c)onstituye un común denominador de todas las medidas cautelares, penales y civiles, que puedan disponerse en el proceso penal el que su fumus boni iuris o presupuesto material que justifica su adopción estriba en el fundado juicio de imputación que ha de formarse el Juez de Instrucción sobre la participación del acusado en el hecho punible (arts.503.3 y 589 LECrim.). La asunción por el Juez de Instrucción de dicho juicio de imputación puede hacer nacer en el Juzgador

\footnotetext{
${ }^{20}$ STC 145/1988, de 12 de julio de 1988, citada por Guerrero, "La imparcialidad...", p. 32.

${ }^{21}$ STC 38/2002, de 14 de febrero de 2002, citada por Guerrero, "La imparcialidad...", p. 33.

${ }^{22}$ Montero Aroca cita las sentencias del Tribunal Constitucional STC 11/1989 de 24 de enero; 106/1989 de 08 de junio; 170/1993 de 27 de mayo y 320/1993 de 08 de noviembre. Montero A., Juan. Sobre la imparcialidad del Juez y la incompatibilidad de funciones procesales, Ed. Tirant lo Blanch, Valencia, 1999, p. 68. [cit: Sobre la imparcialidad...].
} 
cierto prejuicio sobre la responsabilidad penal del imputado que compromete, subjetiva y objetivamente su imparcialidad para conocer de la fase de juicio oral contra un acusado con respecto al cual adoptó durante la instrucción cualquier género de medida cautelar, y basta con constatarlo así para dispensar a este Tribunal del examen que, desde el punto de vista de la imparcialidad objetiva, pudieran proporcionar otras resoluciones y actos de investigación practicados por el Juzgado de Instrucción...".23

Ciertamente alguien podría señalar que no es posible efectuar una comparación entre el juez civil y el juez de instrucción penal, pero lo que interesa destacar es que la argumentación no deja de ser similar a la hora de ver que existe un problema de imparcialidad en que sea el mismo Juez civil el que dicte la medida cautelar y luego conozca del juicio.

La discusión sobre las medidas cautelares, penales y civiles, es una actividad en donde los jueces, como sabemos, evalúan tanto el fumus bonus juris y el periculum in mora siempre con la vista puesta en el juicio. En la práctica, ello implica que necesariamente deben evaluar y ponerse en el caso de que la pretensión del solicitante le sea favorable. Este análisis se efectúa en base a todas la pruebas disponibles al momento de la solicitud y, por lo general, éstas no varían mucho durante el curso del procedimiento. Quieén ha presentado una demanda ha reunido por lo general información suficiente para presentarla, ha explorado alguna otra vía extrajudicial, tiene claro que medios probatorios están en poder de la contraparte, etc. Asimismo, esta solicitud se efectúa por regla general de forma contradictoria, lo que implica que la contraparte deberá demostrar al juez por qué su versión es la correcta para así evitar la medida sobre los intereses de su representado. Siendo así, aun cuando no sea la sentencia definitiva, en la práctica esta decisión no es sino un prejuzgamiento del caso por el juez. Tal como lo señala el profesor Francisco Ramos Méndez, "(I)a medida cautelar tiene sentido en cuanto anticipa en todo o parte la ejecución al momento inicial del juicio y se convierte en un seguro de la eficacia del mismo". ${ }^{24}$ Según Ramos, la medida cautelar "se arbitra como una especie de regulación provisional de la situación litigiosa, en puntos más o menos amplios, pero sensibles, para sobrevivir transitoriamente durante el procedimiento. Ello se consigue adelantando el resultado final del juicio a esta etapa inicial, en función de determinados parámetros establecidos por la ley". ${ }^{25}$

\footnotetext{
${ }^{23}$ Montero, "Sobre la imparcialidad...", p. 69.

${ }^{24}$ RAMOS M., Francisco, Enjuiciamiento Civil. Cómo gestionar los litigios civiles, Tomo I, Ed. Atelier, Barcelona, 2008, p. 516. [cit:Enjuiciamiento Civil...T.I".].

${ }^{25}$ Ramos M., Enjuiciamiento Civil...T.I, p. 517. La Cursiva es del autor de este artículo, no del original.
} 
En la práctica, según las entrevistas realizadas, prácticamente en la totalidad de los casos en que un tribunal concede una medida cautelar la decisión termina favoreciendo al solicitante de la misma. La situación puede ser más grave considerando que existe la posibilidad de solicitar y decretar medidas cautelares sin la comparecencia de la contraparte, afectando la contradicción, pero con un fin distinto más atendible. En este caso, se termina afectando doblemente a la parte afectada, por un lado, no tuvo la posibilidad de rebatir la imposición de la medida y, por otro, no tiene la posibilidad de hacer ver al juez su versión de los hechos, juez que, finalmente, termina prejuzgando su situación.

\subsection{Motivos del legislador para no dividir estas funciones}

Del preámbulo de la LEC es posible distinguir tres argumentos utilizados por el legislador para no proceder a la división de funciones. El primero de ellos dice relación con una especial consideración personal-profesional de los jueces. Pero ¿qué significa que todos los jueces y magistrados están en condiciones de superar impresiones provisionales para ir atendiendo imparcialmente a las sucesivas pretensiones de las partes? A juicio de este autor, lo anterior demuestra un acto de confianza del legislador hacia los jueces. Ello obviamente no es objetable en tanto es evidente de que debemos partir de la base que los jueces cumplirán su función. Pero más allá de confianza el legislador parece suponer una suerte de virtud moral superior o capacidad intelectual superior de los jueces. Sin embargo, los jueces son humanos y, como tales, tienen defectos y virtudes, se ven sometidos a rutinas de trabajo, suelen tener sobrecarga laboral, etc. El problema es que no se trata de confiar o no en la figura de los jueces, sino más bien de evitar todas aquellas situaciones en que una persona se pueda ver afectado por una decisión no imparcial del tribunal. Por otro lado, no parece existir una diferencia respecto a los jueces penales. En este sentido, más allá de las loables intenciones del legislador, esta no parece una argumentación seria a la hora de adoptar una decisión político-legislativa que pone en riesgo una garantía judicial.

Una segunda explicación es que el legislador pareciera haber estimado que el juez del proceso está en mejores condiciones para decretarlas y/o revocarlas, atendido su conocimiento del caso. Pero viéndolo desde el otro lado, ¿qué impediría a un juez distinto conocer y resolver mejor una medida cautelar? ¿Acaso no debe evaluar los mismos requisitos? ¿Quién más objetivo que un juez distinto para conocer de ello? Alguien podría esgrimir que el proceso civil implica el conocimiento de documentación o medios más complejos, pero ello no parece ser un buen argumento. Finalmente, lo debatido sobre una cautelar son hechos, basados en pruebas, por tanto, no parece existir una argumentación que de primacía a un juez sobre otro.

Un tercer argumento dice relación con que dividir las funciones implicaría una mayor complejidad procesal. Ahora, ¿qué debemos entender por compleji- 
dad procesal? ¿Se refiere a que se deben generar nuevos articulados? ¿A que se deben incorporar más funcionarios? ¿A que se incorporan más actuaciones para las partes? Esta argumentación del legislador no hace mención, por ejemplo, a estudios o experiencia comparada que demuestren efectivamente su mayor costo o su mayor complejidad procesal.

En la práctica, el número de procesos con medidas cautelares son menores y por tanto, quizás, no pareciera tener un impacto que demandase una inversión estatal en otro tipo de jurisdicción. Según una jueza entrevistada, en el año anterior su tribunal conoció aproximadamente 10 medidas cautelares en todo el año. De estas, son menores las que no se dictan en audiencia. A su vez, en zonas de menor población, por cierto, podrían generarse inconvenientes prácticos por el número de jueces, pero tratándose de zonas jurisdiccionales grandes, no pareciera que hubiese inconvenientes en distribuir esta función entre los diversos jueces civiles, considerando principalmente los proyectos en curso de oficina judicial común y división de plantas jurisdiccionales.

\section{Posibilidad del juez de advertir la insuficiencia probatoria y proponer prueba}

El segundo problema que será abordado tiene, al igual que el anterior, directa relación con la imparcialidad objetiva del juez. Tal como se hizo presente, el juez, conforme al art. 429 de la LEC, tiene la posibilidad en la audiencia previa de manifestar la insuficiencia probatoria e incluso señalar la prueba o pruebas que estime convenientes. A juicio de este autor, la posibilidad que se otorga al juez de manifestar la insuficiencia probatoria y de proponer prueba puede poner en cuestión seriamente la imparcialidad del juez.

En cuanto a la facultad del juez para decretar la insuficiencia probatoria, el art. 429 establece esta como una facultad, quien de estimar que la prueba es insuficiente para esclarecer los hechos controvertidos, lo podrá poner de manifiesto a las partes. Según Ortells Ramos, esta sería una función de colaboración con las partes "para evitarles perjuicios derivados del defectuoso modo de asumir su iniciativa...". ${ }^{26}$ Luego, puede señalar las pruebas que estime convenientes, pudiendo las partes completar o modificar sus proposiciones de prueba. Por un lado, desde un punto de vista práctico, si como parte se me informa por el juez que decidirá el caso que falta prueba para probar un hecho que disputo ciertamente, si me favorece, aceptaré la eventual sugerencia de prueba que me propone el juez. Si no me propone prueba, pero me manifiesta la insuficiencia, intentaré ver que otra prueba puedo ofrecer, que no había pensado, para lograr mi

26 Ortells R., Manuel, Derecho Procesal Civil, $10^{\circ}$ ed., Ed. Aranzadi, Navarra, 2010, p. 361. [cit:Derecho...]. 
objetivo. O bien, si no estoy de acuerdo con el juez en cuanto a la insuficiencia, pero no veo problema en la prueba para mi posición, aceptaré esta "sugerencia" del juez. Pero, si la prueba que se sugiere me es perjudicial, si claramente había notado que, producto de la impericia, la contraparte no se percató de esa falta de prueba, o si aun cuando no lo había notado pero creía -como el juez- que el caso de mi contraparte no tenía sentido o forma de probarse, ¿por qué en el plano estrictamente privado del derecho civil el juez debe subsidiar el trabajo o la posición de la contraparte? Cualquier litigante con un mínimo de experiencia podrá suponer que, salvo excepciones, cuando un juez le dice que la prueba es insuficiente lo que le está diciendo es que el caso va por un mal camino y que no tiene un buen futuro. Ello es peor cuando quien manifiesta eso es el mismo juez que va a decidir el caso. Básicamente, le está poniendo la lápida encima al caso a no ser que, como se verá, se tome el camino que él puede sugerir.

A juicio de este autor, lo que debería suceder es que en caso de que el juez estime que hay insuficiencia probatoria, o bien, omite esta información y espera a que se ventilen las pruebas en la audiencia de juicio, o bien, una vez terminada la audiencia previa, dicta una resolución que ponga término al proceso precisamente por esa razón. Ya podrán las partes recurrir de la misma. Podría señalarse que ello requeriría que los jueces siempre estudiaran el caso antes de ir a la audiencia previa, lo que al parecer no resulta habitual, pero también podría ponerse el acento en el deber que cabe a las partes de efectuar un ejercicio argumentativo convincente que permita al juez estimar la suficiencia de la prueba.

En cuanto a la sugerencia de prueba, ello exige necesariamente que el juez realice un análisis o prejuzgamiento del caso para tomar la decisión. El juez necesariamente se debe representar cuál de los medios de prueba le parecen a él suficientes para demostrar un hecho. Esa prueba debe necesariamente conducir o no a algo que el juez ha debido analizar en su fuero interno. De lo contrario, no tendría sentido que el juez propusiese algo que puede llevar a la misma situación que provoca la sugerencia. Si de A se desprende B entonces pasa C. Si no se desprende B, entonces pasa D. La anterior es una forma muy básica para decir que el juez debe adelantar esos posibles escenarios para estimar que una prueba es necesaria en el proceso. El punto en cuestión es que sea C o $\mathrm{D}$, esos escenarios afectarán necesariamente los intereses de una de las partes, de forma tal que al decidir el juez estará necesariamente favoreciendo a una y perjudicando a la otra sin que sean las propias partes las que hayan tenido la ocurrencia de la prueba. El Juez, el Estado, no tiene por qué subsidiar la impericia o falta de conocimientos de quienes concurren ante los tribunales. No estamos hablando de un juez de instrucción penal, sino de un proceso privado en que las propias partes, ajenas al Estado, han decidido solicitar la intervención de un tercero imparcial para que resuelva su conflicto que, en principio, no tiene ningún interés público en juego. ¿Por qué subsidiar a una parte entonces? 
Doctrinariamente se ha tratado de justificar esta normativa recurriendo, por ejemplo, a la distinción entre fuente y medio de prueba ${ }^{27}$, o bien haciendo presente que en la medida que exista contradicción no se afecta la imparcialidad del juez. Según Ramos Méndez, la crítica que apunta a que esta facultad puede alterar la igualdad de armas carece de sentido ya que, según él, el juez tendría una "posición de neutralidad jurídica garantizada por el ordenamiento".. ${ }^{28}$ Llama la atención de este autor la posición que al respecto adopta el profesor Ramos considerando principalmente la visión práctica con la cual este profesor suele abordar las temáticas procesales. A juicio de este autor, si existe un cuestionamiento a esta facultad desde la imparcialidad exigible al juez civil. Esta se pone en duda cuando se propone prueba, aun cuando podamos encontrar o crear explicaciones doctrinarias para salvar esa diferencia, ya que proponer una prueba implica necesariamente la adopción por el tribunal de una decisión que puede favorecer o perjudicar a una de las partes de forma previa al juicio que deberá conocer. Como lo señala Palomo Vélez, "la manifestación judicial de los hechos que se podrían ver afectados por insuficiencia probatoria implica un juicio de valor que merma la imparcialidad del juez, en cuanto supone la indicación de hechos aducidos por una de las partes y no por la otra. Por ello, debieran ser las partes las únicas autorizadas a proponer las pruebas" ${ }^{29}$

Cabe hacer presente que, como bien señala Montero, a la hora de abordar la iniciativa probatoria del juez, la LEC presenta un modelo confuso que responde, principalmente, a un trasfondo político que hay detrás del modelo de la LEC y su discusión parlamentaria. Evidentemente, decidir si se da o no al juez una capacidad como esta responde, netamente, a una decisión política. Según Montero, detrás del art. 282 de la LEC hay una concepción liberal garantista que entrega la plena iniciativa a las partes y otra que recoge una concepción autoritaria, surgida principalmente en el debate parlamentario, que terminó con una "solución de compromiso" algo confusa en la LEC. ${ }^{30}$ La Jurisprudencia también ha hecho eco de esta confusa regulación, la cual ha planteado un debate

\footnotetext{
${ }^{27} \mathrm{Al}$ respecto, véase Ríos LópEZ, Yolanda. “¿Puede el juez, al amparo del art. 429.1, II LEC, proponer una fuente de prueba distinta de la ya propuesta por las partes? ¿Es necesario que la prueba propuesta conste nominatim en los autos, o basta que se desprenda de los mismos?", en ABEL, Xavier y PICO I JunOr, Joan (Coords.), Problemas actuales de la prueba civil, Ed. Bosch. Barcelona, 2005, pp. 315 a 350.

${ }^{28}$ Ramos Mendez., Francisco, Enjuiciamiento Civil. Cómo gestionar los litigios civiles, Tomo II, Ed. Atelier, Barcelona, 2008, p. 1337. [cit:Enjuiciamiento Civil... T. II].

${ }^{29}$ Palomo Vélez, Diego, La oralidad en el proceso civil. El nuevo modelo español, Ed. Librotecnia, Santiago, 2008, p. 251. [cit: La oralidad...].

${ }^{30} \mathrm{Al}$ respecto, Montero Aroca, Juan, La Prueba en el Proceso Civil, Ed. Civitas, Navarra, 2011, pp. 533 y ss. [cit: La Prueba...]. También Chico F., Tania, "La Facultad del Juez de indicar la insuficiencia de la prueba propuesta y la preclusión probatoria. A propósito del art. 429.1, II de la ley de enjuiciamiento civil", en Abel LI. X. y Pico I Junoy (Dir.), Aspectos Prácticos de la Prueba Civil, Ed. Bosch, Barcelona,
} 
principalmente en torno a si el art. 429.1 de la LEC se convierte en un deber del juez o se trata de una facultad. La jurisprudencia dominante ha entendido que se trata de una facultad del juez y muchas de ellas han recogido entre las fundamentaciones los problemas que una norma como esta presenta para la igualdad de armas y la imparcialidad del juzgador. ${ }^{31}$ Un ejemplo de ello lo constituye la sentencia del Tribunal Supremo de Santa Cruz de Tenerife STS 19 de mayo de 2003, la cual señala: "4. ${ }^{\circ}$ ) El artículo 429.1 de la LEC no impone la prueba de oficio, es decir, no impone que sea el juez civil quien deba señalar al abogado de la parte las pruebas que ha de proponer para ganar el pleito, pues ello supondría prejuzgar la cuestión planteada e incluso la quiebra del principio de igualdad de armas". ${ }^{32}$

Por cierto, en la práctica, esta facultad no parece ser utilizada por los jueces. De acuerdo a las entrevistas realizadas, ninguno de los jueces entrevistados señaló haber ocupado esta facultad. La razón principal de ello es básicamente que ven en la norma una posible vulneración a la imparcialidad que les exige el debido proceso, en este caso la imparcialidad objetiva que debe mantener el juzgador civil.

\section{Tacha de testigos}

Previo a analizar una serie de problemas en relación al interrogatorio de testigos y partes, parece necesario abordar la figura de la tacha de testigos que aun se encuentra vigente en la LEC. El art. 377 establece la existencia de esta figura y su regulación principal se encuentra entre los artículos 377 y 381 de la LEC. También es posible plantear tachas respecto a los peritos. Cabe señalar previamente que el art. 376 establece el valor probatorio de la declaración de testigo, señalando que se regirá por la sana crítica.

La incorporación de la institución de la tacha de testigos parece innecesaria a la hora de establecer un sistema de valoración de la prueba conforme a las reglas de la sana crítica y disponer de un sistema de producción de prueba en base a un juicio oral. Por un lado, en la medida que, por regla general, cualquier persona pueda ser testigo conforme al art. 361 de la LEC, y que se establece un sistema que permite evaluar la credibilidad del testigo (mediante preguntas de acreditación de testigo, ya comentado) y del testimonio (mediante la posibilidad de contraexaminar al testigo sobre su testimonio bajo el principio de contradicción), un sistema de tacha de testigo parece oponerse a estas ideas.

2006. [cit: Aspectos prácticos...]. Este autor ha utilizado la versión electrónica del documento disponible en VLex http://vlex.com/vid/indicar-insuficiencia-preclusion-probatoria-28853.

${ }^{31}$ Sobre la jurisprudencia, véase Montero, La Prueba..., pp. 536 y ss.

${ }^{32}$ Citada por Montero, La Prueba..., p. 538. 
Según Montero, la tacha "consiste en afirmar y probar la concurrencia de una circunstancia de hecho objetiva en virtud de la cual una persona es sospechosa de parcialidad, por lo que se trata por su medio de poner en guardia al juez para llegado el momento de la valoración de la prueba. La tacha, pues, no excluye a una persona de ser perito, ni priva de valor al dictamen ya presentado" ${ }^{\prime 33}$.

A pesar de lo señalado por Montero, el sistema de tacha responde probablemente a resabios de un sistema escriturado y de tasación legal del valor de la prueba y su fundamentación consiste, básicamente, en que mediante la tacha lo que se pretende en la práctica es eliminar al testigo y su testimonio con el objeto de que la parte de información que este aporte no sea considerada por el tribunal por existir un interés o vínculo del testigo con la parte que lo propone, suponiendo que, dicho vínculo, puede llevar a que el testigo tergiverse, omita o altere la información que proporcionará.

Por un lado, regular esta situación no impide que, en la práctica, quien se presenta como testigo de una parte, tenga o no un vínculo afectivo, familiar o laboral, o sea alguien que está dispuesto a declarar a favor de esa parte, si no fuese así, sería absurdo en pensar que alguien lo ofrecería como medio de prueba propio. Asimismo, no se opone a la situación de que, por regla general, los testigos son preparados por los abogados que los llevan a juicio. Cabe aquí diferenciar preparación del testigo con inducir o hacer que el testigo altere la verdad. Preparar un testigo implica, probablemente, verificar que este se encuentre realmente al tanto de la porción de información que aportará al juicio, verificar que recuerda aquellos detalles que nos interesa queden en conocimiento del juez, verificar con el su destreza o habilidad para declarar verbalmente ante un tribunal y, en su caso, prepararle para enfrentar dicha situación y, por cierto, poner acento en la porción de información que favorece mi versión de los hechos. Visto de esta forma, preparar a un testigo es y debe ser la labor de cualquier abogado litigante diligente. Por otro lado, la versión inducir al testigo a mentir o a que altere la verdad, no resulta apropiada a un sistema de justicia democrático, basado en la buena fe procesal, e implica ciertamente la comisión de un delito no sólo por quien presenta al testigo (sea en figura de obstrucción a la justicia u otra que contemple la legislación) sino también al mismo testigo como autor eventualmente de un falso testimonio.

De ahí entonces que el sistema de tachas se pone en una situación de desconfianza hacia el testigo y hacia quien lo presenta. Pero lo anterior podría haber tenido su justificación si dicha declaración se vertía de forma escrita en un proceso que no se realiza ante un juez. La declaración por escrito ante un funcionario judicial recoge las ideas que dicho funcionario judicial entiende

${ }^{33}$ Montero, La Prueba..., p. 351. 
del testigo. O bien, recoge las ideas creadas por el abogado en un documento. Visto así, un juez que no presencia la declaración, perdiendo aquella parte de información que no es de contenido verbal (gestos, estado anímico, confusiones, etc.) se veía evidentemente expuesto a recibir una información de mala calidad a la hora de juzgar. $\mathrm{O}$ aun cuando fuese el mismo juez quien tomase esa declaración, la misma por escrito no deja registro de estas cosas por lo general. Ello es importante si consideramos que la sentencia -la preparación de la misma- se efectuará, como regla general, tiempo después de la declaración del testigo, por lo que no cabe sino pensar que existe una porción de información relevante que no será evaluada por el juez a la hora de decidir. Por otro lado, en los sistemas escritos, no podía ejercerse a cabalidad la contradicción, no pudiendo por lo general la contraparte someter a un test de calidad la información que era aportada por el testigo de la contraria.

El sistema de tachas supone también de antemano que, por ejemplo, el cónyuge, el empleado o el socio, sí o sí declararán sólo aquella parte que les interesa $\mathrm{o}$, derechamente, mentirán a favor de su pariente. Ya vimos la diferencia entre la preparación y la mentira. Y vimos y sabemos que, exista o no un vínculo, quienes declaran solicitados por una parte es evidente que lo hacen por dicha porción de información que tienen que favorece a quien la ofrece, de lo contrario, no se ofrecería como testigo. ¿Por qué entonces dudar a priori de la calidad de la información del cónyuge, el empleado o el familiar? Efectivamente pueden existir cualquiera de los vínculos señalados pero la información que este aporte puede seguir resultando de gran utilidad para resolver el pleito. Como decía Voltaire en 1785: "todo hombre, quienquiera que sea, puede ser admitido a testimoniar. La imbecilidad, el parentesco, la domesticidad, la infamia misma, no impide que se haya podido ver y oír bien. Es a los jueces a quienes corresponde pesar el valor del testimonio" ${ }^{34}$

Será evidentemente labor de quien presente a este testigo la de demostrar en juicio que, a pesar de todo el vínculo, se aporta una información objetiva (o incluso subjetiva, en su caso) que facilitará la labor judicial. Pero, por otro lado, corresponderá esencialmente a la contraparte el desacreditar al mismo como tal o desacreditar el testimonio. Para ello se requiere un buen ejercicio de contradicción, lo cual requiere, por cierto, un buen entrenamiento en litigación.

Asimismo, la institución de la tacha no parece tener ningún sentido práctico toda vez que tampoco conduce a la eliminación del testigo o perito como tal, sino sólo puede servir para que el juez, al momento de decidir, la tome en cuenta o no en su fallo. Conforme se indicó por la Audiencia Provincial de Huesca: "las tachas no impiden que lo manifestado por el tachado sea tenido en

${ }^{34}$ Citado en Duce/Marín/Riego, "Reforma a los procesos...", p. 61. 
cuenta y valorado por el juzgador si éste adquiere el racional convencimiento de que el tachado se ha manifestado verazmente, de suerte que la concurrencia de una tacha de algún testigo o perito no impide la recta valoración de su declaración,..." ${ }^{\prime 35}$. La Audiencia Provincial de Toledo, al respecto ha señalado que "el artículo 344.2 no obliga al órgano judicial a incluir en su sentencia un pronunciamiento expreso e individualizado sobre la tacha bajo sanción de nulidad de la citada resolución" ${ }^{36}$ Como dice Gómez Colomer, "(I)a formulación de la tacha, incluso en el caso de que la parte contraria se opusiera a ella, no supone que el tribunal dicte resolución alguna. Se trata simplemente de que el órgano jurisdiccional, en el momento de dictar sentencia, deberá tenerla en cuenta para conceder o no credibilidad a lo dicho por el testigo" ${ }^{\prime 37}$

Ramos Méndez, al respecto señala, "(n)o tienen justificación alguna las limitaciones de la prueba de testigos dentro de la propia ley procesal, como por ejemplo, en la prueba de tachas de testigos (379.1) y peritos (343.2). Probablemente, la ley está pensando en la facilidad de realización sin demasiado dispendio de organización, pero, ¿cómo se prueba la amistad íntima, la enemistad, el interés directo o indirecto en el pleito, etc.? Con ello se incita sin más al desuso de estos instrumentos de control de las circunstancias que hacen menos creíble un testimonio o una pericia". ${ }^{38}$ En este sentido, la regulación de la tacha parece ser un resabio del procedimiento escrito anterior, de valoración tasada de la prueba, que puede conducir a complicaciones doctrinales y jurisprudenciales innecesarias y evitables, considerando un sistema en que la mejor manera de cuestionar la validez o parcialidad del testigo o perito o de su testimonio será el propio contrainterrogatorio que debería hacerle precisamente quien más interesado está en demostrar al juez los problemas de la información que se aportará.

Las tachas, además, conforme a su regulación, pueden suponer un procedimiento para acreditarlas. Es decir, ha sido el propio legislador quien, olvidando el principio de economía procesal, ha dispuesto de un procedimiento para acreditar algo que, finalmente, no concluye en algo vinculante para la decisión del juez. Lo anterior puede hacer el sistema más lento, costoso y engorroso.

Si se piensa en las cifras dadas inicialmente, el volumen de casos que conoce el sistema, etc., y considerando que el uso de esta institución en la práctica es muy escaso, pareciera sensato eliminar esta figura y, complementado esto con que sean las partes y no el juez quienes realicen las preguntas de acreditación

\footnotetext{
${ }^{35}$ Montero, La Prueba..., p. 351, comentando SAP Huesca de 30 de diciembre de 2008.

${ }^{36}$ Montero, La Prueba..., p. 353, comentando SAP Toledo de 03 de mayo de 2002.

${ }^{37}$ Gomez C., Juan Luis, y otros, Derecho Jurisdiccional, Vol. II Proceso Civil, Ed. Tirant Lo Blanch, Barcelona, 2010, p.334. [cit: Derecho Jurisdiccional Vol. II...]

${ }^{38}$ Ramos M., Enjuiciamiento Civil... T. I, p. 715.
} 
de los testigos, como se verá a continuación, se podría obtener un sistema que genere información de mejor calidad, con menos trabajo.

\section{Interrogatorio de testigos y partes}

Como en parte se pudo apreciar recientemente, la prueba testimonial, la forma en que ésta se prepara y produce, y la información que de ésta resulta, tiene directa relación con la calidad de la decisión judicial que resulta del caso. Para ello sin duda resulta necesario garantizar los principios de contradicción, inmediación e imparcialidad. A continuación se abordarán una serie de problemas que, a juicio de este autor, obstaculizan en la práctica todo lo anterior.

\subsection{Preguntas iniciales obligatorias, la legitimación del testigo e interrogatorio del juez}

El art. 367 de la LEC establece una listado de temas sobre los cuales debe preguntar el juez al testigo antes de la declaración. Entre estas preguntas, además de la identificación del testigo, se encuentra si tienen vinculación a alguna de las partes, si está al servicio de alguna de ellas, si tiene interés directo o indirecto, si hay amistad o enemistado, si ha sido condenado por falso testimonio, etc. Conforme al inciso final de la norma, está permitido al tribunal profundizar mediante interrogatorio sobre todo ello y permite a las partes manifestar problemas de imparcialidad del testigo. Atendido su contenido obligatorio, las preguntas se realizan habitualmente en la práctica.

La disposición presenta algunos inconvenientes y resulta contraria a la lógica de un proceso en donde la prueba se produce en un juicio oral. A juicio de este autor, la norma puede prestarse para que el juez, mediante su actividad interrogatoria, facilite o subsidie la impericia de la otra parte, afectando la igualdad y poniendo en juego la imparcialidad del juzgador. Si a quien corresponde interrogar a los testigos propios y contrainterrogar de la contraria es a las partes, pareciera ser que, a fin de asegurar la calidad de información que ingresa al tribunal, debieran ser estas mismas las que realicen o cuestionen la credibilidad del testigo. Es evidente que el tribunal debe tener la facultad inicial de verificar la identidad del testigo, fijar sus antecedentes básicos y efectuar las advertencias legales que se derivan de su declaración ante el tribunal. En su labor de control y orden del mismo, además de su calidad de autoridad pública, corresponderá a él informar y prevenir al testigo de las implicancias legales de su testimonio.

Ahora bien, lo que persigue la norma más que identificar al testigo es verificar los compromisos o grados de vinculación de éste con una de las partes, para evaluar a partir de sus respuestas la objetividad o imparcialidad de su versión. Eso es, en definitiva, un primer test de control de calidad de la información que será ventilada en el juicio. Siendo así, es el propio abogado que presenta el 
testigo quien debiera tener mayor interés en que no se cuestione la credibilidad y confiabilidad de la versión que se aporta por este. Por otro lado, quien tiene mayor interés en desacreditar el testimonio o la persona del testigo es la contraparte. Ciertamente al tribunal le interesa saber de ambas cosas, porque ello le permitirá evaluar la información que aporta dicho testigo a la resolución del conflicto. Al juez civil le importa dirimir de la mejor forma posible el conflicto jurídico que se presenta ante él, pero no es su prioridad velar por el crédito moral de quienes declaran y menos le importa que parte del conflicto se verá beneficiada o perjudicada por su decisión, de lo contrario, existiría un compromiso de su imparcialidad. Si el testigo aporta buena o mala información para el caso es un problema que debe repercutir en las partes, quienes son los verdaderos afectados o beneficiados por la decisión del tribunal. Siendo así, corresponde a las partes efectuar el control de la información, tanto de los problemas de la fuente en cuanto a su credibilidad como del contenido de la misma y no debiese estar en manos del juez esta posibilidad, precisamente, porque el juez no está para subsidiar la falta de preparación o destreza de los abogados de las partes para validar a su testigo y la información que este aportara.

Cuando el juez subsidia a una de las partes está predisponiéndose necesariamente a favor de ésta, o bien está asumiendo funciones de instrucción que no son propias del juez civil. Lo anterior afecta la igualdad de las partes, poniendo en tela de juicio su imparcialidad. Como lo señala Montero, "(u)na cosa es conceder al juez facultades para corregir y subsanar los defectos en que hayan incurrido las partes en la realización de los actos procesales, e incluso que instruya a las partes de los presupuestos que condicionan la validez del acto, y otra cosa muy distinta que se convierta en abogado de una de las partes frente a la otra" ${ }^{39} \mathrm{Si}$ el testigo declara mal o la información que aporta no es relevante, eso es un problema para uno y un acierto para el otro, pero no debiera ser del interés del juez civil. Que un testigo tenga un vínculo estrecho con una de las partes no le impide ser un testigo, no le impide aportar información de calidad, y no le impide ser una buena fuente de información. En la práctica, una persona sin vínculo alguno con la parte o el abogado, por múltiples razones imaginables (sentimiento de justicia, remordimientos personales, problemas de percepción de la realidad, etc.) puede transformarse en la peor y más parcial fuente de información. Tanto un pariente, un empleado o un extraño pueden tergiversar o manipular la información, afectando a una de las partes, de ahí la principal labor que constituye para los litigantes el test de credibilidad del testigo y testimonio.

\footnotetext{
${ }^{39}$ Montero A., Juan y otros, Derecho Jurisdiccional, Vol. I Parte General, Ed. Tirant Lo Blanch, Barcelona, 2010, p.341. [cit: Derecho Jurisdiccional Vol. I...]
} 
Por otro lado, la norma no parece acorde a la lógica de valoración de la prueba conforme a la sana crítica. Resulta más propia de un sistema legal de valoración. Es cierto que la norma no le dice al juez cómo debe decidir en torno a ello, es decir, no le dice textualmente que si el testigo es pariente de la parte no debe ser considerado. Lo mismo sucede con la tachas, como se comentó anteriormente. Pero a pesar de no decirlo es claro que el mensaje tras dicha regulación es que este tipo de situaciones son perjudiciales a la imparcialidad y credibilidad del testigo, se advierte al juez de ello, lo cual necesariamente condiciona inicialmente la valoración que haga el juez. Es el punto de partida. Así, pareciera invertirse la carga probatoria en este punto, quien presenta al testigo relacionado debe necesariamente probar su credibilidad so riesgo de ser necesariamente considerado poco creíble, aun cuando la contraparte nada plantee sobre el tema. Sin duda, existe una herencia inquisitiva tras esta norma, propia del sistema antiguo escriturado de prueba tasada. Si detrás de la norma no está ese mensaje, y si se cree que esas situaciones, de acuerdo a la experiencia, pueden ser mayormente problemáticas debería ser el juez capaz de llegar a dicho razonamiento, sin necesidad de que el legislador le recuerde o le condicione.

El subsidio a una de las partes sobre este punto puede afectar también las estrategias jurídicas que, en la práctica, tengan los litigantes. Todo litigante medianamente responsable enfrentará el litigio definiendo una estrategia a seguir durante el desarrollo del caso, en este caso del juicio. Cabe señalar que la referencia se hace a estrategia, no a estratagema ${ }^{40}$. Por ejemplo, es factible que un litigante conociendo los testigos que presentará su contraparte, un no pariente por ejemplo, disponga de una línea de preguntas de cuestionamiento que evidencian que, a pesar de no ser pariente, la persona tiene un interés indirecto (aunque no sea evidente para él) en que se resuelva a favor de quien declara, por ejemplo, porque este cree (no sabe, ni hay nada estipulado ni conversado) que podrá obtener futuros contratos de servicio. A pesar de ello, y a pesar de que dirá toda la verdad durante el juicio, el juez al iniciar el juicio ha preguntado a ese testigo, conforme a la ley, sobre todos los aspectos que dispone, incluyendo sus intereses indirectos en el asunto. El testigo, de buena fe, puede responder que no tiene ningún interés indirecto en el asunto, pues no lo tiene. Del asunto mismo nada obtendrá el directa o indirectamente. El juez, por su parte, no realiza más preguntas al respecto. El litigante, convencido de que tiene una línea interrogatoria sobre este tema decide plantear esta a la hora de efectuar las preguntas. Sin embargo, su contraparte cuestiona la pregunta, o, más claramente, el juez la rechaza directamente por tratarse de un tema ya

40 "Astucia, fingimiento y engaño artificioso". Diccionario Real Academia Española, $22^{\circ}$ Ed. www. rae.es. 
preguntado por él al inicio. En la práctica, sucede este tipo de limitaciones en general para preguntar sobre algo ya contestado. De esta manera, el tribunal, a propósito de su función, ha limitado las posibilidades estratégicas de una de las partes y, de paso, se ha quedado sin una porción de información relevante para la resolución del caso.

Vale la pena señalar también que, en la práctica, existirán muchas ocasiones en que ninguna de las partes dudará acerca de la credibilidad del testigo y, por tanto, decidirán no realizar estas preguntas por ser innecesarias. Puede suceder también, por ejemplo, que si siendo un deber de las partes y una de estas no prepara bien esa línea de interrogación preferirá no "salir a pescar", es decir, no ir a preguntar aquello cuya respuesta desconoce y que le puede ser perjudicial, por lo cual no utilizará la opción.

En la práctica, de todas las audiencias observadas, las partes no parecen interesadas en legitimar a sus testigos ni en desacreditar a los de la contraparte, no pudiendo apreciar ningún ejercicio de interrogatorio de legitimación (a favor o en contra) durante los juicios observados. Por otro lado, las preguntas iniciales que realiza el juez responden en la práctica a una especie de rutina. Esto, probablemente, también responde a la existencia en la ley de esta fase de preguntas. Las partes entienden que es labor del tribunal y dejan de verlo como una función en interés suyo, a pesar del impacto que puede tener en la información producida un buen ejercicio de acreditación. El sistema se queda sin un porcentaje importante de información que permitiría una mejor resolución de asuntos. Así, la norma funciona como un incentivo perverso para que las partes no preparen esta importante labor, a pesar de ser los más interesados, dejándola en manos del juez, el menos interesado en quien gana o pierde el litigio. El juez, por su lado, lo toma como un trámite más, necesario para la continuidad de uno de los tantos juicios que tiene, dentro de los miles de caso que lleva su tribunal. Es evidente que siempre existirán casos que concentrarán toda la atención de las partes y el juez sobre este punto pero, como se aprecia en la práctica, en el caso promedio o cotidiano no parece ser de relevancia. Visto así, la norma puede afectar la imparcialidad y va en contra directamente, en la práctica, de la calidad de la información producida en juicio, algo que debiese importar a los litigantes y a los jueces.

\subsection{La declaración de la propia parte}

El legislador español ha establecido una diferencia entre un testigo y la parte. Si bien esta diferencia es usual en los ordenamientos para distinguir nominalmente y en relación a ciertos deberes y derechos, llama la atención que contemplándose un modelo de juicio oral contradictorio se distinga también a la hora de presentarlos a declarar en juicio. Existe una diferenciación doctrinaria al respecto que, evidentemente, sustenta esta distinción efectuada por el legislador. Al respecto, 
por ejemplo, José Luis Seoane Spielberg señala: “(L)a solución adoptada por el legislador, en el actual artículo 301.1, es la correcta, en tanto en cuanto admite la posibilidad de instar la declaración de un colitigante, no privando a los contendientes de tal fuente de prueba, que puede resultar trascendente a la hora de dirimir responsabilidades y definir derechos; pero limitando coherentemente su viabilidad a los supuestos en los que concurra entre los litisconsortes un real 'proceso de oposición o conflicto de intereses'". ${ }^{41}$

Según Montero Aroca, el legislador podría haber optado por incorporar el interrogatorio de la parte como medio de prueba pero que, en una decisión política, se optó por ello para acabar con el juramento, como institución vinculada a la confesión, aun cuando lo podría haber incorporado sin necesidad de juramento. Como decisión política, según Montero, sólo podría criticarse desde ese plano ${ }^{42}$.

El punto es que, finalmente, en la práctica, más allá de las consideraciones doctrinales, parte y testigo cumplen un mismo rol en el juicio oral, aportar información relevante (o no) al juez para que este tome la decisión sobre el litigio. Según Ramos Méndez, "no existe probablemente una gran diferencia entre la declaración de una parte y la declaración de un testigo". ${ }^{43}$ Además, señala que "(I) a nueva ley ha regulado un híbrido, que no es la antigua confesión, ni tampoco, en los papeles, el interrogatorio de los testigos. Digo que 'en los papeles', porque la práctica ya lo ha percibido de otra manera, ha asumido el cambio de filosofía, y ya lo viene tratando, sin ninguna estridencia, como un interrogatorio más" ${ }^{44} \mathrm{Es}$ decir, la exclusión del interrogatorio de la parte como medio de prueba de la LEC es posible no sólo cuestionarla políticamente sino también desde la práctica.

Que declare o no la parte a la que se representa debiera ser siempre una decisión jurídica estratégica de quien representa los intereses de la misma, considerando que, a la hora de declarar, se verá expuesta a un contrainterrogatorio y a las posibles aclaraciones del juez. Esto puede beneficiar a la parte pero también puede perjudicarla, según su testimonio sea creíble o no, según si su letrado logra mediante el interrogatorio extraer de él la información que se quiere transmitir al tribunal, etc.

Si bien la doctrina y jurisprudencia mayoritaria, anterior y posterior a la nueva LEC, han compartido la exclusión del testimonio de la propia parte, otros autores como Torres Pinado han entendido que la declaración de la propia parte

\footnotetext{
${ }^{41}$ En prólogo de AbeL LlunCH, Xavier (Dir.), El interrogatorio de las partes en la Ley 1/2000, de Enjuiciamiento Civil, Ed. Bosch, Barcelona, 2008, p. 18.

42 Montero, La Prueba..., p. 240.

${ }^{43}$ Ramos M., Enjuiciamiento Civil... T. I, p. 692.

${ }^{44}$ Ramos M., Enjuiciamiento Civil... T. I, p. 692.
} 
debiera aceptarse conforme al art. 24.2. de la Constitución. ${ }^{45} \mathrm{~A}$ favor de esta posición estarían también Lorca Navarrete, Serra Domínguez, Pico i Junoy y Bonet Navarro, estos últimos ven también una restricción del derecho a la prueba en relación con el derecho a la defensa. ${ }^{46}$ Otros autores como Ramos Méndez han incluso señalado que esto debiese ser modificado. Al respecto señala que "(e)n una próxima reforma legislativa, hay que dar el paso que queda para acomodarse a la realidad de las cosas: regular unitariamente los interrogatorios de personas, con unas mismas normas simplificadas. Ganará claridad el sistema y nos ahorraremos no pocos artículos" ${ }^{47}$

Conforme a la LEC, presentar a declarar a una parte al juicio sólo puede ser solicitado por la contraparte. Desde el punto de vista práctico del ejercicio de litigación, lo anterior trae como consecuencia que la decisión queda en manos de la contraparte, potencial perjudicado con el testimonio de la parte. Esto se transforma en un arma que deja en indefensión a la misma parte toda vez que, aun cuando haya establecido su pretensión en los escritos de demanda, se puede ver imposibilitada de entregar su versión de cómo suceden los hechos en disputa en "el" momento ideado para hacerlo, el juicio oral, privando al juez de esa parte de información que solo ella puede aportar. En relación a ello, a juicio de este autor no parece justificable considerar que lo que se establece en los escritos es propiamente la declaración de la parte ya que lo que éstos contienen -la información que de ellos emana- es una versión de los hechos y solicitudes efectuada por el abogado conforme a su criterio jurídico y no un relato de los hechos que emane como información directamente de la parte.

Se presenta, asimismo, otro problema desde el punto de vista de la litigación: ¿cómo deben ser las preguntas que formula el abogado que ofrece a la contraparte? Si es éste quién debe iniciar el interrogatorio, y evidentemente se trata de una declaración contraria a sus pretensiones (de lo contrario jamás se hubiese legislado sobre las respuestas evasivas o negativa a declarar) y que, por tanto, tenderá a entregar en su respuesta aquella parte de información que le es conveniente, ¿puede hacer preguntas sugestivas? ¿podría el abogado de quien está declarando objetar preguntas? Este problema pone de relieve otra situación que será abordada en el próximo punto, cual es, la deficiente o ambigua legislación en torno a la forma en que deben efectuarse las preguntas, lo cual se aprecia en la práctica.

\footnotetext{
${ }^{45}$ Torres Pinado, David, "Aspectos subjetivos en el interrogatorio de las partes", en Abel/Pico i Junoy, Aspectos prácticos..., pp. 283-290. [cit: Aspectos subjetivos...]. Este autor ha utilizado la versión electrónica del artículo disponible en VLex http://vlex.com/vid/aspectos-subjetivos-interrogatorio-288534.

${ }^{46}$ TORres, Aspectos subjetivos..., p. 6.

${ }^{47}$ Ramos M., Enjuiciamiento Civil... T. I, pp. 692 y 693.
} 
Un litigante avezado sabrá, como sucede en la práctica, que no debe solicitar jamás la declaración de la parte si no le es conveniente a sus pretensiones jurídicas. Esto lo sabrán mejor, sobre todo, los abogados con mayor experiencia en un sistema oral y menos contaminado con el escriturado anterior. En este sentido, si lo que se pretende es obtener del juicio oral la mejor información para que el juez decida, y existiendo la posibilidad de contrastar la información aportada, esta decisión no puede quedar en manos sólo de la contraparte -a quien en la práctica se le ha entregado un arma para el "juego sucio"- sino que debe estar también en manos del abogado de la parte. Como señala Ramos Méndez, "...la parte, a quien la ley otorga la posibilidad de solicitar la declaración de su oponente, se lo piensa dos veces, antes de pedir una prueba que puede volverse contra ella. La escena es sarcástica en casos en que apenas aparecen como candidatos a declarar las propias partes. Muchos litigantes son renuentes a pedir la declaración de la parte contraria, para obviar el riesgo del contrainterrogatorio" ${ }^{48}$

\subsection{Preguntas compuestas y sugestivas. Examen y contraexamen}

La forma en que debe realizarse el interrogatorio está regulada de forma algo similar para partes y testigos. Respecto al interrogatorio de las partes, los artículos 301 y siguientes de la LEC dan las pautas para ello. La declaración de los testigos está regulada en los artículos 360 y siguientes. Según el art.302, las preguntas a las partes deben realizarse oralmente en sentido afirmativo, con claridad y precisión. Asimismo, señala que no deberán incluir valoraciones ni calificaciones, y si éstas se incorporan se tendrán por no realizadas. ${ }^{49} \mathrm{El}$ interrogatorio cruzado está contemplado en el art. 306 de la LEC y, de cierta forma, en el art. 372.

Los artículos 303 y 369 incorporan las normas que permiten objetar las preguntas. La regla permite impugnar la admisibilidad de las preguntas haciendo notar las valoraciones y calificaciones que contenga la pregunta y que se estimen improcedentes. A pesar del diferente contenido y objetivo que, en la práctica, tienen unos y otros, esta normativa no distingue entre impugnación de preguntas del examen de la parte que ofrece el testimonio y la impugnación de preguntas realizadas en el contrainterrogatorio. El problema no se presentaría ante esta falta de distinción sino más bien en la poca claridad respecto a las preguntas sugestivas y al contrainterrogatorio.

Preguntas sugestivas son aquellas que contienen en sí misma su propia respuesta. El problema que se presenta con estas preguntas es que la información

${ }^{48}$ Ramos M., Enjuiciamiento Civil...T. I, p. 706.

${ }^{49}$ El presente comentario no abordará la discusión sobre qué debe entenderse por preguntas afirmativas, algo que parece estar claro doctrinal y jurisprudencialmente. 
es otorgada por el letrado que la efectúa y no por la parte o testigo que declara, por lo cual la fuente de la cual proviene la información que valorará el juez es el abogado y no la prueba. Lo anterior tiene especial trascendencia en relación a los testigos que se presentan de propia parte. Ello por cuanto, al tratarse de una parte o testigo proclive por lo general a esa versión del litigio, tenderá a entregar esa parte de información que favorece esa línea. En caso de no recordar o saber una información relevante permitimos que la entregue el abogado que lo presenta y no que emane de la declaración. Además, quién mejor que ese abogado para entregar, como cree conveniente, la información al juez. Así, se pone en juego la calidad de la información que llega al conocimiento del tribunal para que este decida.

La situación es radicalmente distinta tratándose de un interrogatorio cruzado. Como ya se ha dicho, el testigo o parte podría ser evidentemente parcial hacia una de las versiones, y normalmente declarará -de mejor o peor formasegún crea más conveniente a esa posición. Como ya ha sido interrogado por su abogado podrá confiar que informó todo lo que tenía que informar, que lo hizo de la mejor forma, y que pudo omitir (no mentir) aquella parte de información que, eventualmente, puede resultar perjudicial a esa postura. De ahí que al enfrentar el interrogatorio de la contraparte sabe que representa la otra versión en juego, se pone frente a él como un testigo parcial, y tenderá a entregar la información como él crea es más concordante con lo ya declarado y con su visión del litigio. Por ello, los sistemas con amplia tradición en litigación oral permiten expresamente el uso de preguntas sugestivas al litigante que no presenta al testigo o contraparte, precisamente porque se trata de un testimonio parcial, o incluso hostil, que tenderá a aportar la menor información posible a favor de la otra versión. Así, es necesario que pueda utilizar preguntas sugestivas si quiere sacar a la luz del juicio la información que crea relevante y puede legítimamente pensar que no se hará voluntariamente por el declarante. Ello pone en evidencia una de las problemáticas mencionadas en el punto anterior en relación a la imposibilidad de presentar a la propia parte y como debe interrogársele.

Preguntas compuestas son aquellas que contienen más de una pregunta en la formulación de la pregunta que se efectúa. El problema con las preguntas compuestas es que inducen al testigo en un error "pues por lo general se lo invita a responder a la última pregunta contenida en la frase, pretendiendo que cuando la responde lo está haciendo también respecto de todo el resto de la información". ${ }^{50}$

\footnotetext{
${ }^{50}$ Baytelman, Andrés; Duce, Mauricio, Litigación Penal, Juicio Oral y Prueba, Ed. Universidad Diego Portales, Santiago de Chile, 2004, p. 226.
} 
Si bien la LEC no utiliza expresamente los términos sugestivas ni compuestas, sí es posible desprender del propio texto legal dichos requisitos. Como lo ha señalado la Audiencia Provincial de Almería en SAP 02 de diciembre de 2002, "(C)iertamente que la ley procesal advierte que las preguntas a las partes y testigos han de ser hechas en sentido afirmativo, con la debida claridad y precisión, sin incluir en las mismas valoraciones ni calificaciones, sin embargo ello no significa que el requisito de la formulación afirmativa excluya e impida efectuar preguntas abiertas, siempre que no sugieran la respuesta, engañen al declarante o le pidan una valoración del hecho" ${ }^{51}$ Por su parte, en relación a la claridad y precisión exigida en el art. 302.1 de la LEC, ello en parte implica que "cada pregunta ha de referirse a un hecho, sin que en la misma se mezclen varios extremos...". ${ }^{52}$ Como señala el profesor Palomo, "la insuficiencia de la normativa que regula esta fase del interrogatorio es notoria y patente y seguirá requiriendo de una interpretación que la complete coherentemente con las necesidades que impone el nuevo modelo oral de interrogatorio" ${ }^{\prime 53}$

En la práctica, el uso de las preguntas sugestivas y compuestas resultó ser habitual a la luz de las observaciones de este autor. En cuanto a las preguntas sugestivas, el problema está en que éstas son usadas por quien presenta al testigo. Lo anterior tiene más importancia porque la posibilidad de objetar preguntas no parece ser muy utilizada en la práctica, a pesar de que unas y otras, según la jurisprudencia analizada anteriormente, serían plenamente objetables.

Resulta problemática la falta de claridad en la legislación respecto a si quien ejerce labores de interrogatorio cruzado puede efectuar preguntas sugestivas. El problema, como bien destaca Ramos Méndez, es que "(e)n el subconsciente de la regulación legal late sin duda el deseo de importar la cross examination anglosajona, como sugiere el rótulo adoptado en la cabecera de la norma. Pero, desde luego, la ley no parece conocer exactamente en qué consiste la figura". ${ }^{54}$ En relación al interrogatorio cruzado de las partes, el art. 306 de la LEC nada dice. Según Ramos Méndez, "(e)l interrogatorio es cruzado cuando el que interroga es la parte que tiene intereses contrarios con la que declara, no como acontece en el supuesto introducido en la ley española: el abogado repregunta a su propio cliente" ${ }^{\prime 55}$ Tampoco se desprende la posibilidad de efectuar preguntas sugestivas de los artículos 302 o del 303. Tampoco se hace referencia a ello respecto a los Testigos y Peritos.

${ }^{51}$ Citado por Montero, La Prueba..., p. 266.

52 Montero citando STS de 18 de marzo de 1978, en La Prueba..., p. 266.

53 Palomo, La oralidad..., p. 440.

${ }^{54}$ Ramos M., Enjuiciamiento Civil...T. I, p. 707.

${ }^{55}$ Ramos M., Enjuiciamiento Civil... T. I, p. 707. 
En suma, como lo ha señalado Palomo, "(I)a nueva normativa comete el error de no distinguir las notables diferencias que, para el efectivo logro de las muy importantes finalidades del contraexamen, deben existir entre la regulación del interrogatorio principal y la prevista para el contrainterrogatorio" ${ }^{56}$ El problema, a juicio de este autor, es que la no clarificación legal de este tema, aun cuando puedan darse interpretaciones doctrinarias y jurisprudenciales, puede acarrear como consecuencia una interpretación jurídica que no permita la utilización en el contrainterrogatorio de preguntas sugestivas, con lo cual se afectaría el efectivo derecho a contradecir afectando la calidad de las decisiones judiciales.

\subsection{Interrogatorio del juez}

Otra temática interesante al respecto dice relación con la posibilidad de los jueces de efectuar preguntas a los testigos, conforme al art. 372.2. de la LEC. Partiendo de las ideas fuerzas analizadas anteriormente, parece sin duda que la actividad del juez debiera limitarse única y exclusivamente a clarificar ciertos puntos que no han quedado claros de lo dicho por la parte o testigo. Debe evitar el juez introducir nuevos temas en el interrogatorio. Ahí, me parece que la idea de "adiciones" puesta por el legislador puede prestarse para malos entendidos o incentivos perversos. Recordemos que no estamos frente a un juez instructor sino frente a un juez que decide en base a derecho y sobre lo que las partes le llevan a juicio. Como señala Montero Aroca: "El juez de la LEC de 2000 es un juez neutral, imparcial, entre dos partes parciales, y el atribuirle la facultad de hacer preguntas a los testigos que supongan encaminar el interrogatorio por donde no lo han querido llevar las partes es contrario a esa imparcialidad". ${ }^{57}$ Es que, en la práctica, como bien señalan Duce, Marín y Riego, "cada pregunta que se hace en un juicio no viene desde ninguna parte, ni va hacia ninguna parte. Las preguntas vienen desde una versión de los hechos y van dirigidas a corroborarla o desmentirla" ${ }^{58}$ En la práctica es una facultad utilizada por los jueces, pudiendo incluso apreciarla durante el interrogatorio que realizaba una de las partes, interrumpiendo las preguntas de la parte. Más allá de las buenas intenciones de dicho juez, esa actividad, en la práctica, afecta a las partes y pone en riesgo su imparcialidad.

\section{Conclusiones en el Juicio Verbal}

En los sistemas procesales en donde la audiencia de juicio oral es la principal instancia para rendir la prueba y generar la información para la decisión del

\footnotetext{
56 PALOMO, La oralidad..., p. 440.

${ }^{57}$ Montero, La Prueba..., p. 420.

${ }^{58}$ Duce/Marín/Riego, Reforma a los procesos..., p. 75.
} 
juez, el real valor de la información que surge de la prueba testimonial y de la práctica de los otros medios de prueba sólo se obtiene una vez efectuadas las conclusiones de las partes. Es en esta instancia en donde los abogados tienen la posibilidad de relacionar toda la información, incorporar a partir ella sus apreciaciones de hecho y de derecho, desacreditar la forma o teoría que, sobre ésta, tiene la contraparte, etc. De ahí la trascendencia práctica de la conclusiones y, por ende, la necesidad de garantizar su ejercicio.

La LEC no establece en la vista del Juicio Verbal una instancia para conclusiones sobre la prueba que puedan efectuar las partes. A juicio de este autor, la carencia de una instancia como esta no sólo afecta las posibilidades efectivas de las partes de plantear su versión sobre el asunto sino, lo que es más importante, impide a estas plantear sus conclusiones respecto a medios probatorios cuyo contenido -en cuanto a la información que ingresa al tribunal por el medio- no era conocido hasta la audiencia.

Esto afecta también la calidad de la información con la cual debe decidir el juez. Recordemos que la contradicción ejercida respecto a los medios de prueba ofrecida por la contraparte permite, en esencia, ejercer la labor de un filtro de la calidad de la información desde quién más interesado está en que llegue la mejor información a quién decide. La contradicción, sabemos, "busca que las partes tengan la posibilidad efectiva de manifestar su punto de vista e intervenir en la formación de convicción por parte del tribunal que tiene que resolver sobre los derechos y obligaciones debatidos" ${ }^{\prime 59}$ Como sabemos también, no es posible en el interrogatorio que las partes efectúen opiniones o conclusiones dentro de sus preguntas de modo que la conclusión se transforma en el espacio donde las partes, junto con entregar su versión definitiva del asunto, ahora con la información obtenida o no de la prueba, pueden contradecir también la versión entregada por la otra parte. De esta forma, impedir ello afecta la calidad de la información que llega al tribunal, el derecho a contradecir las pruebas de la contraparte y, finalmente, la calidad de las decisiones judiciales.

Se desconoce los motivos del porqué el legislador decidió excluir la referencia a las conclusiones en materia de juicio verbal. Ahora bien, como destaca Maroto Márquez, "la doctrina entiende que tal silencio no debe interpretarse en un sentido prohibitivo de unas alegaciones que pueden resultar de gran utilidad y los tribunales debieran permitir no pocas veces las conclusiones e incluso informes..." ${ }^{\prime 60}$. Es más, según Ramos Méndez, éstas se pueden realizar y en ello la doctrina sería unánime. ${ }^{61}$ En el Preámbulo de la LEC no es clara la referencia,

\footnotetext{
${ }^{59}$ Duce/Marín/Riego, "Reforma a los procesos...", p. 36.

${ }^{60}$ Maroto Marquez, Joaquín, "El Juicio Verbal", en Gutiérrez-Alviz, "Exposición...", p. 102.

${ }^{61}$ Ramos M., "Enjuiciamiento Civil...T. II", p. 1562.
} 
pero podrían desprenderse de ahí argumentos a favor. En éste, podría interpretarse que el legislador, al hacer alusión someramente al diseño de los procesos declarativos y al tratar el juicio oral, se refiere también a la audiencia de vista -que, en una parte, no es sino un juicio oral- del juicio verbal. El Preámbulo señala expresamente que "(e)n el juicio, se practica la prueba y se formulan las conclusiones sobre ésta..." sin hacer mención a si se refiere al juicio oral o al verbal, pero resultaría lógico creer que se refiere a ambos.

A pesar de la supuesta unanimidad de la doctrina que señala el profesor Ramos Méndez, las aprehensiones antes señaladas se han reflejado en alguna doctrina y jurisprudencia. Como señala Cucarella, "(e)sta situación normativa, ha generado la controversia acerca de si las alegaciones conclusivas son o no posibles en el juicio verbal. Si acudimos tanto a la jurisprudencia como a la doctrina científica, podemos detectar que hay diferentes posturas al respecto".. ${ }^{62} \mathrm{En}$ relación a la jurisprudencia, este autor señala dos argumentaciones que han sido seguidas por la jurisprudencia para no permitir las conclusiones. El primero, que la ley no las prevee expresamente, citando para ello fallos como el SAP Badajoz 311/2004 de 12 de noviembre (sec $2^{\circ}$ ) y SAP Barcelona 248/2005 de 28 de abril (Secc $2^{\circ}$ ). El otro argumento utilizado, según Cucarella, ha sido que lo que pretendió el legislador era que fuese dictada la sentencia inmediatamente después de la prueba. Cita para este último un fallo SAP Segovia 178/2006 de 31 de julio $\left(\sec 1^{\circ}\right) .{ }^{63}$

Aun cuando doctrinariamente pueda estimarse la concurrencia de conclusiones en el juicio verbal, lo concreto es que, en la práctica, no se ven estas con mucha frecuencia. Ello puede deberse a múltiples razones: falta de tiempo, cargas laborales, desinterés de las partes, etc. Pero ante el silencio de la LEC, la falta de conclusiones podría deberse también a una interpretación del propio juez. El juez podría tener razones de texto para ello aun cuando detrás de su decisión puntual puedan influir otros motivos. Por ejemplo, y considerando la carga laboral, puede suceder perfectamente que realizando un juez su cuarta audiencia en la mañana le toque conocer de un juicio verbal de "poca" trascendencia para su tribunal. El juez, consciente que debe regresar a su despacho a firmar algunas providencias, terminar resoluciones de juicios vistos el mismo o días antes, y luego de haber escuchado y presenciado las pruebas de este caso en particular cree en su interior, honestamente, que ya sabe qué decisión adoptará sobre el caso. Una parte con un sólido argumento para concluir, le solicita

\footnotetext{
${ }^{62}$ Cucarella G., Luis-Andrés, "El trámite de las conclusiones en el juicio verbal", en Carpi y Ortells (Ed.), Oralidad y escritura en un proceso civil eficiente, Vol. II, Ed. Universitat de Valencia, Valencia, 2008, p.350. [cit: "El trámite..."].

${ }^{63}$ Cucarella, “El trámite...", p. 351.
} 
hacerlo, pero para el juez ya fue suficiente y, ante la petición de la parte, que mejor argumento de rechazo que el hecho que la ley no lo establezca.

No me interesa juzgar las intenciones o calidad de los jueces, por cierto su labor es ardua y abnegada, pero quienes han ejercido rol de litigantes -en cargos públicos fundamentalmente- en sistemas orales con alta carga de trabajo, sabrán que este tipo de decisiones no expresas suceden en la práctica. De ahí entonces que, más allá de las intenciones o buen criterio de los actores, resulta necesaria la expresa mención legal de las conclusiones en este tipo de procedimiento, como una etapa más que, de no realizarse, tenga consecuencias jurídicas relevantes, como, por ejemplo, la nulidad.

Por último, Ilama la atención que esta situación no haya sido corregida legalmente -más allá de interpretaciones jurisprudenciales ${ }^{64}$ - a pesar de haberse constatado su ausencia antes de la entrada en vigencia, como queda de manifiesto en el texto de Maroto Márquez, a pesar de que la LEC ha sufrido modificaciones desde su entrada en vigencia y, principalmente, atendido el porcentaje de casos que representan los juicios verbales en el sistema y que se quiere ampliar aumentando su cuantía. En definitiva, esto puede afectar el derecho de las partes a contradecir y puede afectar también a los destinatarios del sistema, al impedírsele a su representante hacer las conclusiones, pero también al no obligar la ley a que se realicen estas, por la trascendencia de la conclusión sobre la decisión judicial ${ }^{65}$, más allá de los ánimos de su abogado o de las restricciones de tiempo del juez.

Como ha señalado la Audiencia Provincial de Burgos en Sentencia de 12 de febrero de 2003 "una interpretación del artículo 447.1 de la LEC, que supusiese la no audiencia de los interesados acerca de lo sucedido en el juicio supondría una interpretación de la ley que dejaría a las partes sin la posibilidad de poner de relieve aquellos datos que pueden tener trascendencia para dar lugar a la

\footnotetext{
${ }^{64}$ En este sentido, Solano señala: "La jurisprudencia de las Audiencias Provinciales no es unánime en la cuestión de los efectos que hay que otorgar en el caso de denegación por el tribunal, previa petición de parte, del trámite de conclusiones en un juicio verbal. Por una parte, existen sentencias que han declarado la nulidad de actuaciones en el caso de que, previa petición expresa de una parte, el tribunal de instancia denegó la práctica de conclusiones. Por otra, existen otras sentencias que han desestimado el recurso de apelación interpuesto contra la sentencia de instancia, en el mismo supuesto". Solano M. Miriam, "Incidencia de la oralidad en la formulación de las conclusiones: de la instructa a las conclusiones orales", en Abel/Pico i Junoy, Aspectos prácticos..., p. 15. [cit: "Incidencia..."]. El autor ha accedido al presente artículo en VLex. http://vlex.com/vid/rali-dad-formulacion-instructa-orales-288543.

${ }^{65}$ Como destaca Miriam Solano, argumentos similares se han esbozado en este sentido. Solano señala: "Existen otros argumentos que no tienen un fundamento legal tan evidente, pero que llegan a la misma conclusión. Se argumenta que [las conclusiones] constituye un medio puesto al servicio de las partes para contribuir a formar la voluntad del órgano jurisdiccional. Desde este punto de vista, las conclusiones constituirían una garantía de los justiciables y no meramente un trámite superfluo". Solano, "Incidencia...", p. 12.
} 
resolución que se dicte, lo que supondría una interpretación limitadora de los derechos de audiencia de los interesados, lo que se pone difícilmente en relación con el derecho de defensa de los interesados en el juicio". El mismo tribunal ha señalado que "la limitación en los medios de defensa de las partes por una causa no expresamente prevista en la ley, como es el caso de autos, donde no se ha permitido a las partes una última alegación sobre el resultado de las pruebas practicadas y sobre los fundamentos de su defensa, y una vez que por la parte hoy apelante se recurrió dicha decisión de modo expreso, no es admisible en nuestro ordenamiento jurídico al limitar indebidamente los derechos de las partes y... procede decretar la nulidad de lo actuado...". ${ }^{66}$

La Audiencia Provincial de Castellón se ha pronunciado en sentido similar al señalar que "el artículo 185.4 LEC regula con carácter preceptivo que el juez o tribunal, después de practicada la prueba, conceda de nuevo la palabra a las partes para el anteriormente llamado trámite de conclusiones y ahora de alegaciones. Ello es consustancial al principio de contradicción o audiencia que preside todos los procesos y que desde una perspectiva constitucional viene contemplado en el artículo 24.1 de la Constitución, cuyo contenido esencial está integrado por la necesidad de ser oído y que no puede vulnerarse por un procedimiento en la actualidad predominantemente oral, en el que el juez se pone en contacto directo e inmediato con las pruebas personales (testigos y peritos) y con las partes" ${ }^{\prime 67}$

Podría incluso cuestionarse su legitimidad constitucional, por tratarse de una eventual vulneración del debido proceso, pero ello excede el contenido de este trabajo por el momento. Sin duda, la indeterminación del legislador ha llevado a una disyuntiva que, de haberse utilizado una mejor técnica legislativa, o bien de haberse precisado con claridad la intención del mismo, hubiese evitado este tipo de interpretaciones doctrinales y jurisprudenciales que han tratado de acomodar la legislación a su pensamiento, pero que, a juicio de este autor, han dejado en indefensión a las partes en todas aquellas oportunidades en que la jurisprudencia o la práctica judicial no lo han entendido o dispuesto así. Como lo señala Cucarella, "(e)s evidente que la situación de silencio normativo a la que nos estamos refiriendo, no es la deseable, en la medida en que genera dudas e inseguridades. Desde nuestro punto de vista, a pesar del silencio, debe realizarse un esfuerzo interpretativo con el objeto de dar una solución respetuosa con el derecho de defensa de las partes y con la regulación procesal general. Compartimos las posiciones de la doctrina que entiende que las conclusiones son "una garantía y no un trámite superfluo". ${ }^{68}$

\footnotetext{
${ }^{66}$ SAP de Burgos de 12 de febrero de 2003, citada en Solano, "Incidencia..." p. 15.

${ }^{67}$ SAP Castellón de 19 de noviembre de 2003, citada en Solano, "Incidencia...", p. 16.

${ }^{68}$ Cucarella, "El trámite...", p. 355.
} 


\section{Posibilidad de dictar pruebas de finales}

Continuando con el análisis de los problemas, y a pesar de que el juicio oral se encuentre prácticamente terminado a estas alturas del trabajo, el art. 435 de la LEC establece una posibilidad que, a juicio de este autor, plantea algunos problemas que vale la pena abordar. Este artículo dispone la facultad para que a instancia de parte (435.1.) o excepcionalmente de oficio (435.2.) se realicen diligencias probatorias finales durante el período siguiente a la terminación del juicio. Según Ortells Ramos, esta sería una función de colaboración con las partes junto con la dispuesta en el art.429.1 de la LEC, derivada en este caso de dificultades ajenas a las partes "que han impedido que su iniciativa diligente conduzca a la práctica de las pruebas propuestas..." ${ }^{69} \mathrm{~A}$ juicio de este autor, no se presentan mayores complicaciones con lo dispuesto en el artículo 435.1 toda vez que sus requisitos y exigencias sólo permiten esta posibilidad tratándose de prueba nueva, desconocida y relevante, o bien la práctica de pruebas admitidas que no se pudieron realizar por motivos ajenos a quien la propuso. La regulación en este sentido ha limitado de forma precisa esta facultad para evitar, precisamente, que se alteren los principios dispositivo y de aportación de parte o se afecte la imparcialidad del juzgador.

El problema se presenta respecto del apartado 2 del art. 435, o diligencias excepcionales, como las ha definido Montero $^{70}$. La primera de ellas tiene que ver con la posibilidad de que el juez de oficio determine un medio probatorio. De acuerdo a la norma, estas diligencias pueden ser dispuestas de oficio por el juez, lo cual puede afectar la igualdad de las partes y se puede ver seriamente afectada la imparcialidad objetiva del juzgador. En palabras de Chiovenda, "(e)n un sistema que admitiese la investigación de oficio de la verdad de los hechos, el reparto de la carga de la prueba no tendría razón de ser" ${ }^{\prime \prime 1}$. Como se indicó anteriormente, a pesar de las buenas intenciones del juzgador, resulta inevitable que el juez no realice un prejuzgamiento para tomar una decisión de proceder a una prueba de oficio. Porque para hacerlo, el juez debe necesariamente visualizar un problema en la probanza de los hechos o en las versiones de alguno de los litigantes $y$, frente a ese problema, debe pensar cual a su juicio es el medio probatorio más idóneo para remediar dicho problema. No tendría ningún sentido que el juez escogiera al azar un medio probatorio, se pone en juego su prestigio y profesionalidad. Si ha de escoger uno lo hará desde su experiencia profesional porque cree que dicho medio es el adecuado. Que

\footnotetext{
${ }^{69}$ Ortells, Derecho..., p. 361.

${ }^{70}$ Montero, La Prueba..., p. 553.

${ }^{71}$ Montero, La Prueba..., p. 123.
} 
finalmente el medio propuesto no de los resultados esperados puede deberse a múltiples factores, incluso a que los litigantes no sepan extraer de él la información relevante, aunque probablemente veamos a un juez más interesado en que dicho medio arroje la información requerida, quizás lo veamos efectuando más preguntas de lo habitual, etc. Es decir, en la práctica, inevitablemente con esta posibilidad el juez cargará la balanza hacia uno de los dos lados y dejará de ser el tercero imparcial que debe dirimir el conflicto. Lo anterior por cierto no tiene nada que ver con cuestionar la independencia del juez o sus mejores intenciones, pero ningún juez o litigante podrá desconocer que esta decisión es potencialmente perjudicial para una de las partes en conflicto.

En segundo lugar, esta facultad puede ser utilizada por el juez para corregir una mala decisión jurídica tomada durante el proceso. No se hace referencia a la posibilidad de enmendar un error formal, de transcripción, etc., sino a la posibilidad de revertir decisiones jurídicas. Por ejemplo, como sucedió en SAP Málaga de 23 de julio de 2004, en la cual la Audiencia Provincial de Málaga confirma la decisión adoptada por un juez de instancia de decretar de oficio la rendición de una prueba propuesta por las partes en la audiencia previa pero que el mismo juez rechazó en ella atendido que, según el juez, la cuestión era simplemente jurídica. ${ }^{72}$ No estamos hablando aquí de una decisión que vulnere derechos procesales, existen otras vías para ello. Estamos hablando de lo que constituye en esencia la labor judicial, tomar decisiones en derecho. Esa decisión puede ser, a nuestro juicio, correcta o incorrecta y por eso los sistemas cuentan con recursos jurídicos de diversa índole, pero no parece razonable ni conveniente que los jueces puedan ir dejando sin efecto sus decisiones porque han reconsiderado la misma, que borren con el codo lo que se escribió con la mano, porque ello afecta la seguridad jurídica que esperamos de las decisiones, buenas o malas, que ha tomado el juez. Además, porque esta nueva decisión puede no haber sido objeto de debate por los afectados y porque, de cierta forma, se ha convertido en un derecho adquirido para una de partes. Como litigante puedo ya contar con que el juez, por ejemplo, no aceptó un medio probatorio de mi contraparte. La estrategia jurídica y de litigación en el caso considerará sin duda esa posibilidad o incluso cómo enfrentar los posibles recursos que utilice la contraparte, por lo que una decisión como ella puede afectar el razonable derecho que tienen las partes de preparar su estrategia.

En tercer lugar, esta facultad del modo en que está legalmente establecida, se puede transformar en una vía para que las partes subsidien su falta de preparación. Por ejemplo, como sucedió en SAP Toledo de 28 de enero de $2004^{73}$. En

\footnotetext{
72 Montero, La Prueba..., p. 554.

${ }^{73}$ Montero, La Prueba..., p. 554.
} 
este caso, por la vía del art. 435.2. LEC se admitió la declaración de un testigo del cual se conocía su existencia, fue nombrado en Audiencia Previa, pero no se propuso como testigo por la parte porque en dicha audiencia esta desconocía su domicilio. Puede resultar poco creíble a quien ha litigado diligentemente que, en la práctica, un litigante que lleva un tiempo preparando el caso o teniendo la posibilidad de recurrir a vías oficiales para determinar un domicilio de un testigo durante el proceso, llegue a la audiencia previa desconociendo la ubicación de un testigo. Si bien esto puede ocurrir ocasionalmente, a juicio de este autor, esta no debería ser la vía adecuada para solucionar este problema.

En cuarto lugar, la norma abre un espacio para que esta vía permita prácticas dilatorias. Si bien en este sentido Montero hace presente que el legislador ha tratado de poner fin a las "diligencias para mejor dilatar" sin un objeto probatorio, el riesgo de que una facultad como aquella se preste para prácticas dilatorias es considerable. Prácticas dilatorias por cierto no sólo de oficio, sino también de partes. Puede resultar poco elegante o políticamente incorrecto decirlo, pero lo cierto es que el sistema de justicia, los honorarios, la necesidad de que no se dicte una sentencia sobre un caso que se sabe perdido, ganar tiempo para realizar otras gestiones jurídicas mientras salga el fallo, etc., son incentivos perversos del sistema que pueden estar presentes en la actividad del litigante. Cuando son de oficio, la situación podría ser peor, considerando las cargas de trabajo en constante crecimiento, la eterna falta de personal y jueces, etc. Como destacó Jaime Guasp en 1945, la actividad probatoria de oficio es una de las principales fuentes de retrasos en el juicio. ${ }^{74}$ Según Montero, no es claro el por qué se dispuso la facultad de oficio, pero probablemente responda a similares observaciones hechas por el autor en relación a la concepción política detrás de la LEC y su debate parlamentario. ${ }^{75}$

En quinto lugar, de forma indirecta se puede ver afectado también el principio de concentración y la inmediación. Si bien formalmente seguirá exigiéndose inmediación del juez, y por cierto deberá ser el mismo juez que conoce el juicio, su dilatación prolongada en el tiempo puede significar, lo que humanamente es advertible, que con la carga laboral el juez, pasado un tiempo de observado el juicio, Ilegado el momento de la prueba conforme al art. 435.2, realizada ésta, deberá recurrir a sus apuntes (si los tomó) respecto a lo que sucedió en la vista del juicio mismo. Con ello finalmente se pierde uno de aquellos objetivos de la inmediación, esto es, que el juez dicte sentencia respecto de los antecedentes que ha percibido por sus sentidos en el juicio y no por la lectura de actas, tal como se analizó anteriormente.

\footnotetext{
${ }^{74}$ Citado por Montero, nota al pie 79 en La Prueba..., p. 554.

${ }^{75}$ Montero, La Prueba..., p. 554.
} 
Incluso autores que están de acuerdo con la posibilidad de que el juez tenga mayor facultad probatoria de oficio resultan igualmente críticos de la normativa. Así, por ejemplo, Ramos Méndez señala "(c)omo para mitigar el remordimiento de la restricción impuesta al tribunal, se le acaba dando a posteriori lo que siempre debió tener: la posibilidad de acordar pruebas de oficio. Es una especie de compromiso tardío". ${ }^{76}$ Seguidamente, Ramos indica que:"(I)a orientación legislativa debe solucionar el jeroglífico de la forma más sencilla: reconociendo iniciativa probatoria al tribunal sin más, como se ha hecho con los árbitros y derogando el tinglado de diligencias finales. ¡Qué alivio!". ${ }^{77}$

Cabría destacar que en el caso del juicio verbal la práctica de las diligencias finales no sería aceptada por la jurisprudencia mayoritaria. ${ }^{78}$ Las razones principalmente son de texto legal, en cuanto esta norma se ubica en relación al Juicio Ordinario. Sin embargo, resulta extraño para este autor que no se efectúe una distinción entre ambas hipótesis del art. 435. Como se ha podido apreciar, ambas responden a motivos distintos y, atendida la simplicidad del juicio verbal, en la práctica existen mayores razones para pensar en la aparición de prueba nueva relevante para el juicio en este procedimiento. Aun cuando se ha esgrimido la simplicidad del juicio verbal para excluir esta posibilidad en dicho proceso, lo cierto es que las razones otorgadas en contra del art. 435.2. para justificar su exclusión del juicio verbal, podrían servir de argumentación también a la hora de excluir el art. 435.2 en el juicio ordinario. Parece un contrasentido del legislador. La relevancia práctica de este problema sin duda surgirá si, como se ha pretendido, se amplía la cuantía de los juicios verbales.

Por último, cabe señalar que esta facultad no sería muy usada en la práctica. En los juicios observados no se observó ni se tuvo conocimiento de su utilización. Al parecer, a veces se utiliza para fijar nuevo día para la declaración de un testigo, pero para hipótesis como aquella sería recomendable establecer una posibilidad de suspensión de la audiencia para estos efectos en vez de dejar abierta una norma que puede conllevar diversos perjuicios al proceso civil.

\section{Demora en la dictación de la sentencia}

Habiendo concluido el juicio, habiéndose practicado toda la prueba posible, habiendo las partes manifestado sus conclusiones al respecto, corresponde ahora al juez realizar aquella principal función que se le ha encomendado: dictar sentencia. La sentencia, se espera, se deberá hacer cargo de las alegaciones y

\footnotetext{
${ }^{76}$ Ramos M., Enjuiciamiento Civil... T. II, p. 1347.

${ }_{77}$ Ramos M., Enjuiciamiento Civil...T. II, p. 1347.

${ }^{78} \mathrm{Al}$ respecto véase Montero, La Prueba..., p. 558.
} 
las posiciones encontradas en juicio y de la información que de este ha surgido. Básicamente es aquí donde el principio de inmediación encuentra toda su justificación. Sin embargo, de la LEC y de la práctica del sistema nuevamente surge un problema. De acuerdo al art. 434 de la LEC, el juez, una vez realizada la audiencia de Juicio Oral o, en su caso, conforme al art. 428, que le permite al juez dictar sentencia inmediata cuando no hay controversia por los hechos, tiene un plazo de 20 días para dictar la sentencia definitiva. En el caso del juicio verbal ese plazo es de 10 días.

Aun cuando ha sido el propio legislador quien ha establecido el plazo de 10 ó 20 días, la ley no contempla ninguna norma en específico que establezca la obligación o deber para el juez de emitir su veredicto en la propia audiencia. Muchos de los juicios realizados son, para los jueces, de baja complejidad y nada obstaría a que el mismo día del juicio emitieran un veredicto acerca del mismo, sin perjuicio de razonar y fundamentar jurídicamente en detalle la sentencia en los próximos días.

El problema que genera lo anterior es que los jueces, por lo general, se ven obligados a revisar sus notas y el expediente que consta en el tribunal para emitir su fallo. Lo anterior tiene repercusiones en la inmediación toda vez que, con este principio, lo que se persigue es precisamente que el juez obtenga sus conclusiones a partir de la información recibida directamente en la audiencia y no que deba recurrir a la lectura del expediente para poder fundamentar su fallo. Como señala Montero, el principio de Inmediación supone "que el juez ha de tener contacto directo con las fuentes de prueba, pero esa relación directa se justifica en que su certeza sobre los hechos debe formarse sobre lo visto y oído, no sobre el reflejo documental de los medios de prueba..."79. Una consecuencia de ello, como señala Montero, es que sea el mismo juez que aprecia las pruebas quien dicte la sentencia, pero otra consecuencia lógica de este principio es que, mientras más días pasen menos recuerdos se tendrán de dicho acto. Si solo fuese la única actividad de ese juez, puede ser, pero cuando recaen sobre ese juez un gran número de casos y gestiones administrativas por las que debe velar durante ese período, es muy difícil que, en la práctica, no se termine revisando el expediente documental del caso. Como bien señala Montero, "(I)a inmediación no es simplemente un principio atinente a la presencia judicial en determinados actos orales, sino que afecta a algo más profundo como es la manera como se determina la convicción judicial; ésta se forma de modo directo con lo visto y oído en el acto, no con lo leído en el acta que documenta la realización del acto ni con la visión de lo grabado durante la realización del acto".. ${ }^{80}$

${ }^{79}$ Montero, La Prueba..., p. 205.

${ }^{80}$ Montero, La Prueba..., p. 213. 
Recordemos que el expediente contiene las alegaciones que las partes formulan en sus escritos de demanda y contestación, puede incluir cartas o declaraciones notariales de testigos, informes en derecho, y una serie de otros elementos que no necesariamente fueron ventilados en el juicio siendo, por tanto, antecedentes que pueden no haber sido contrastados en juicio o información que no formó parte del juicio. Si lo esencial del proceso es el juicio y en éste, para ser tal, debe regir el principio de inmediación, lo correcto sería que el juez, con lo allí ventilado, emitiese su fundamentación. El transcurso del tiempo da pie para un ir y venir de decisiones en el propio juez quien, además, debe no sólo lidiar con ese caso sino con muchos otros que debe conocer cotidianamente. Puede suceder entonces que con el transcurso del tiempo un juez no recuerde bien que fue lo que dijo un testigo, o lo que anotó en sus apuntes personales, por múltiples razones, no sea lo más relevante de la declaración de ese testigo. A partir de esto, disminuye la calidad de la información con la que el juez puede y debe decidir.

Por otro lado, y considerando el escaso debate que en general se da sobre el contenido de los documentos (no aquí sobre su autenticidad), la forma en que un juez interprete un determinado documento que está en el expediente y el cual le sirva para su decisión puede no haber estado sometida a la contradicción y, como consecuencia, más allá de la afectación al derecho de las partes a controvertir, la calidad de la información con la que decidirá el juez nuevamente se ve afectada. Recordemos que la contradicción como tal lo que persigue es que la información que ingresa al tribunal, que llega a conocimiento del juez, sea de la mejor calidad posible. En este sentido, quien mejor está preparado para efectuar un control de la calidad de la información que ingresa durante el juicio es la propia parte que se verá afectada por ella y que de antemano conoce el testigo o documento que será presentado.

Un problema que se presenta en la práctica es que el plazo que se establece en la ley de 10 ó 20 días para dictar la sentencia no se cumple prácticamente nunca. Este autor ha tomado conocimiento de casos que han superado los 6 meses entre la realización del juicio y la dictación de la sentencia. Ello sin duda agrava los argumentos anteriores. Cabe señalar que conforme al art. 211.2. de la LEC, la inobservancia del plazo para dictar la sentencia sólo da lugar a corrección disciplinaria, salvo que medie justa causa, que se hará constar en la misma sentencia. Es decir, la misma ley, de cierta forma, facilita la posibilidad de que un juez no dicte en plazo la sentencia. Sin duda esto debe ser analizado puesto que el exceso en la carga de trabajo sumado a una norma permisiva, resulta ser un fuerte incentivo para la dictación de sentencias en plazos prolongados y, con ello, para que recobre más importancia el expediente y las notas que lo que surja del juicio oral. Extremando el punto anterior, ello podría conducir a la delegación de funciones internas, solicitando el juez la ayuda de funcionarios 
subalternos para la redacción de la misma. Se debe señalar en todo caso que no se tienen antecedentes de que esto último suceda en la práctica.

En definitiva, como se preguntan Duce, Marín y Riego, "ipara qué diseñar todo un sistema oral que garantice la inmediación si, en el último momento, el de la decisión más importante y para la cual se realizó todo el proceso, se dicta la sentencia de la misma manera que en el antiguo procedimiento escrito? ¿Hay un juicio oral si el juez forma su decisión a través de un acta y no de la audiencia?". ${ }^{81}$

\section{Carencia de programas de litigación}

"Después de siglos de vigencia de un proceso civil escrito, la vuelta a la oralidad en actos procesales que poco antes eran escritos requiere un proceso de adaptación de todos los profesionales que intervienen en el proceso" ${ }^{\prime 2}$

Un último aspecto que quisiera destacar, y que tiene vinculación directa con todos los temas abordados anteriormente, dice relación con la apreciación de este autor de que, a pesar de la consolidación del sistema oral, se observa un bajo nivel de litigación en los litigantes que no parece acorde al estado y evolución del sistema. Como se desprende de las palabras de Solano, el desarrollo y perfeccionamiento de un sistema de litigación oral requiere no sólo actores preparados en cuanto a conocimientos jurídicos, lo cual es la base, sino también preparados para enfrentarse a un modelo completamente distinto al escriturado tradicional. Esto es fundamental considerando que un sistema basado en audiencias orales es un sistema que, por regla general, no es tolerante frente a los desconocimientos jurídicos o a la falta de entrenamiento que pueden ser suplidos con comodidad cuando se realizan escritos en un despacho.

Así, un sistema que tenga como base la realización de audiencias orales requiere de cambios culturales, cambios en las costumbres de los abogados y cambios en los modelos de enseñanza jurídica ${ }^{83}$, entre estos, la incorporación del

${ }^{81}$ Duce/Marín/Riego, "Reforma a los procesos...", p. 71.

${ }^{82}$ Solano, "Incidencia...", p. 20.

${ }^{83} \mathrm{Al}$ respecto, Alberto Binder señala: "Existe otra función central de la audiencia oral. Ello es uno de los instrumentos centrales de la conformación de la cultura judicial. Solemos utilizar con mucha frecuencia la idea de cultura jurídica o judicial. Las reformas de la justicia, por ejemplo, tendrán éxito o no pueden afincarse por problemas 'culturales'. De hecho durante mucho tiempo se sostuvo que las diferencias entre los modelos inquisitoriales y adversariales dependían de cuestiones culturales, como si ambos no se originaran en la base románico-germánica que constituye la cultura europea. Claro que está que la historia moldea todos los procesos y también el propio del desarrollo de los sistemas judiciales, pero no es cierto que exista algo así como una 'idiosincrasia nacional' que impida que se respeten los derechos humanos y las garantías judiciales. Cuando hacemos referencia a la cultura jurídica nos referimos, en realidad, a las costumbres de los abogados, a esa especial persistencia en sus rituales y formas de trabajo. Es ese apego al formalismo, al escriturismo, a formularios lo que constituyen un obstáculo. Pero justamente realizar 
entrenamiento en técnicas de litigación. Dichas habilidades, por regla general, no son adquiribles solo mediante la lectura de un manual o libro, requieren de entrenamiento y práctica. ${ }^{84}$ Más aún, cuando las destrezas aprendidas en la práctica jurídica escriturada son formas muy difíciles de desarraigar. Como señala Solano, un hecho que viene aparejada a la oralidad es, por ejemplo, en relación a las conclusiones, "la instantaneidad con la que deben realizarse las conclusiones al término de la práctica de la prueba. Ello implica una veloz actividad de cada letrado para ordenar tanto sus alegaciones como la relevancia de cada medio de prueba practicado".$^{85}$ Ella lo ve como un problema que lleva a justificar la necesidad de dar tiempo a los letrados para preparar sus conclusiones. Pero más allá de eso, lo que está en el fondo del asunto, es que todo lo anterior hace necesario el desarrollo de cursos o actividades de formación en niveles de pre y post grado, es decir, la existencia de una oferta de calidad en esta materia, que permita entrenar en técnicas de litigación a todos aquellos litigantes y jueces que participan o participarán en el futuro en el sistema.

Sistemas con tradición en materia de litigación oral, como el norteamericano, dan mucha importancia a este tipo de entrenamiento y habilidades o Trial Advocacy, por cierto materia propia de todos los ámbitos del derecho y no solo del penal. ${ }^{86}$ En Chile por ejemplo, uno de los factores que influyeron exitosamente en la implantación de un sistema acusatorio oral en materia penal a partir del año 2001 fue la importancia que se dio a los programas de formación en técnicas de litigación oral ${ }^{87}$. Chile venía de un sistema de justicia criminal completamente escriturado por lo que el cambio de mentalidad y prácticas era fundamental si lo que se pretendía era instaurar un sistema basado en la orali-

acciones para superar esa situación de sometimiento del conjunto de la sociedad a formas de trabajo de los abogados es también uno de los objetivos del proceso de reforma. Lo que todavía no hemos hallado con claridad es el conjunto de instrumentos que nos permitan hacer esa superación. En particular, porque las Escuelas de leyes siguen apegadas a formas tan antiguas de ejercicio profesional que inyectan atraso en los procesos de reforma. Sin embargo, ya sabemos que existen algunos instrumentos con mayor eficacia, para cambiar esa cultura o, por lo menos, para ponerla en cuestión. Entre todos ellos, la audiencia oral -realizada de un modo masivo, como el lugar permanente de trabajo del abogado- constituye sin duda uno de los más eficaces". Binder, Alberto. "Elogio de la Audiencia Oral y Pública". Ponencia presentada en el XXVI Congreso Nacional de Derecho Procesal, Universidad Nacional del Litoral. Santa Fe, Argentina, junio de 2011, p. 11. Disponible en http://www.procesalsantafe2011.com/?page_id=194.

${ }^{84}$ Al respecto, véase BAYTELMAN, Andrés, "Capacitación como fútbol", en Revista Sistemas Judiciales $N^{\circ}$ 1, 19 de agosto de 2002, Centro de Estudios de Justicia de las Américas, Santiago de Chile, p. 27. Disponible en www.sistemasjudiciales.org . [cit: "Capacitación..."].

${ }^{85}$ Solano, "Incidencia...", p. 20.

${ }^{86}$ Existen en Norteamérica una serie de instituciones tanto nacionales como locales dedicadas a este entrenamiento. Una de ellas, por ejemplo, el National Institute for Trial Advocacy, www.nita.org.

${ }^{87} \mathrm{Al}$ respecto, véase Baytelman, "Capacitación...". 
dad. Así, las nuevas instituciones ${ }^{88}$ dedicaron mucho de su tiempo y recursos al entrenamiento de los actores en técnicas de litigación, lo cual fue abordado principalmente por algunas universidades privadas con docentes preparados en el sistema de litigación norteamericano ${ }^{89}$, las cuales a su vez ofrecieron diversos cursos de técnicas de litigación a los abogados privados. Tal fue la conciencia de la necesidad de implantar estas prácticas que las instituciones desarrollaron diversas capacitaciones y ejercicios interinstitucionales previo a la entrada en vigencia del sistema. Existen sin duda diferencias entre el sistema de justicia civil y el penal, pero en muchos aspectos la implementación de un sistema de justicia con base en audiencias orales responde a lógicas comunes.

Algunas de las observaciones realizadas en este trabajo responden, precisamente, a la aparente carencia de formación de los litigantes españoles en este ámbito. Por ejemplo, en relación a los interrogatorios que se efectúan por las partes. En este punto, Ilama la atención que más que preguntas muchos de los abogados emiten opiniones que son consultadas a las partes. Es decir, desde el punto de vista del ejercicio de la litigación, Ilama la atención que quienes aportan una parte importante de la información son los abogados, no los testigos que declaran. Básicamente, como se analizó, quienes presentan a un testigo efectúan generalmente preguntas sugestivas al momento de interrogarlo y, por tanto, la información importante para el juicio ingresa principalmente a través de los abogados y no del propio testigo. A su vez, se efectúan demasiadas preguntas compuestas, como también se abordó. Sin embargo, no parece existir mayor cuestionamiento a lo anterior ni por las contrapartes ni por el tribunal. Como se dijo, si bien la ley contempla la posibilidad de objetar preguntas, en todos los juicios observados no se presentaron objeciones a las preguntas efectuadas por la contraparte aun cuando fuesen notoriamente sugestivas. Lo anterior fue confirmado también en las entrevistas. Ello no parece ser un tema que preocupe a los intervinientes aun cuando la información ingrese por el abogado de la contraparte o sea de muy baja calidad y aun cuando este tipo de ejercicio permitiría obtener mejor información y el desarrollo de mejores estrategias de litigación para las partes. En algunas audiencias de procedimiento abreviado en materia penal se pudo apreciar la misma situación.

A modo de anécdota, destaca que revisados los catálogos web de las Bibliotecas de dos universidades (Universidad Pompeu Fabra y Universidad de Barcelona) no existen mayores publicaciones sobre técnicas de litigación,

\footnotetext{
${ }^{88}$ En Chile, a propósito de la Reforma Procesal Penal, se crearon el Ministerio Público, la Defensoría Penal Pública y se crearon nuevas figuras judiciales como los jueces de garantía y los Tribunales Orales en lo Penal.

${ }^{89}$ En este sentido, referente fue la Universidad Diego Portales. Al respecto, puede verse el Programa de Reformas Procesales y Litigación de la Universidad en www.reformasprocesales.udp.cl.
} 
ni en español ni en inglés ${ }^{90}$. Al parecer, tampoco existe entrenamiento sobre el particular en las mallas curriculares de pregrado aun cuando la reforma al proceso civil date del año 2000. En materia de posgrado son muy pocos los cursos que profundizarían en estas temáticas ${ }^{91}$. Respecto a ellos, cabe señalar que los contenidos referentes a litigación en materia civil están principalmente destinados a conocer en profundidad las etapas procesales, desde el punto de vista doctrinario y jurisprudencial, la demanda, el análisis de los medios de prueba, la sentencia, la ejecución, los costes procesales, etc. Todos estos temas son sin duda indispensables para ejercer de la mejor forma en un sistema de justicia, conocer su funcionamiento, los criterios judiciales, etc. Sin embargo, no se incorporan en la malla curricular cursos de técnicas o destrezas de litigación en juicios orales, entendiendo por litigación no todos los conocimientos jurídicos necesarios que se mencionaron anteriormente sino técnicas y herramientas para argumentar, interrogar y concluir verbalmente, de forma estratégica y adecuada, en un juicio oral, con la finalidad de obtener la mejor información posible en relación con mi teoría del caso. Un litigante puede conocer toda la jurisprudencia y la doctrina en torno a la valoración de la prueba testimonial o puede conocer las mejores estrategias para acompañar un informe del perito, pero si no es capaz de obtener la mejor información del testigo o perito en el juicio, si no es capaz de rescatar aquel porcentaje de información del testigo o perito de la contraparte que resulta relevante a su teoría del caso, de poco sirve finalmente tanto conocimiento jurisprudencial.

La enseñanza de las técnicas de litigación suponen entonces ver al juicio como un ejercicio estratégico, para lo cual se necesitan destrezas que no necesariamente se obtienen de la mera lectura doctrinal o jurisprudencial. Como señala Andrés Baytelman, "al concebir al juicio estratégicamente, importa asumir que la prueba no habla por sí sola, sino a través de los litigantes, y los

\footnotetext{
${ }^{90}$ Como ejemplo, utilizando la palabra "litigación" en el buscador web de la biblioteca de la Universidad de Barcelona aparecen 4 libros: uno sobre Psicología del conflicto y la litigación; otro sobre Derecho procesal civil internacional y litigación internacional (con 2 ediciones); otro titulado Costes de litigación en el análisis económico de la evasión fiscal y el libro Litigación penal : juicio oral y prueba. En el catálogo web de la Biblioteca de la UPF aparecen dos libros, uno sobre derecho procesal civil internacional y litigación internacional (con 2 ediciones) y otro titulado Daños del amianto: litigación, aseguramiento de riesgos y fondos de compensación. Utilizando las palabras "Litigación Civil", en la UB y la UPF aparece el mismo libro sobre Derecho procesal civil internacional: litigación internacional (con 2 ediciones). Por último, utilizando las palabras "Trial Advocacy", en la UB aparece una publicación y en la UPF dos publicaciones.

${ }^{91}$ Al respecto, véase los contenidos del Máster en Abogacía de la Universidad Pompeu Fabra. Según la información publicada en su sitio web, una de las áreas temáticas es la litigación civil y mercantil. Información disponible en http://www.idec.upf.edu/master-en-abogacia/contenidos-academicos.
} 
litigantes pueden presentarla de manera que ella revele en toda su plenitud la información que posee, o bien pueden hacerlo de un modo que dicha información naufrague en un mar de detalles insignificantes, pase inadvertida por otras miles de razones, pierda credibilidad, omita información o la entregue de un modo que no convoque adecuadamente la atención del tribunal".$^{92}$ Todo esto supone en este plano el cambio de metodologías de enseñanzas tradicionales en el mundo del derecho. Como señala Baytelman, la "premisa metodológica tras la disciplina de litigación, a su turno, consiste en desplazar la imagen de capacitación como 'instrucción' hacia la imagen de capacitación como 'entrenamiento' ${ }^{\prime \prime} .{ }^{93}$

Sin duda, cabe reiterar que a pesar de lo señalado anteriormente, el sistema es efectivamente oral y las audiencias cumplen el rol para el cual fueron diseñadas, no responden a un cumplimiento formal de un trámite legal ni a la lectura de expedientes, lo cual es un gran logro para un sistema que venía de un modelo escrito, pero se pone acento en esta temática sobre todo como una manera de seguir perfeccionando un sistema y, acorde a uno de los objetivos de este trabajo, tener presente algunos puntos a considerar y mejorar a la hora de implementar los procesos civiles orales en Chile y América Latina.

\section{Breves reflexiones en relación al proyecto de Reforma en Chile}

Antes de concluir este trabajo, este autor quisiera abordar brevemente algunos aspectos del proceso de reforma a la justicia civil que se desarrolla actualmente en Chile con el objeto de analizar cómo se han tratado ahí algunos de los problemas abordados anteriormente.

Tal como se ha comentado al inicio de este trabajo, Chile está inmerso en un proceso de reforma de su sistema de justicia civil, como sucede en gran parte de América Latina. Todos ellos tienden a implementar sistemas basados en la oralidad, la publicidad, la contradicción, la inmediación, entre otros principios, con la idea de dejar atrás ineficientes sistemas escriturados y altamente colapsados. Esta lógica ha sido en parte similar a lo sucedido en las últimas décadas en muchos países de la región a propósito de las reformas de los sistemas de justicia criminal.

En Chile, el año 2009 se presentó por el ejecutivo un Proyecto de Código Procesal Civil (en adelante el Proyecto) que recogía toda la experiencia acumulada y elaborada por foros académicos constituidos al efecto y que anteriormente

\footnotetext{
${ }^{92}$ BAYTelman, "Capacitación...", p. 27. Baytelman junto a Mauricio Duce son los autores del único libro disponible en el buscador web de la Biblioteca de la Universidad de Barcelona sobre litigación en juicio oral: Litigación penal: juicio oral y prueba, Ed. Fondo de Cultura Económica, México, 2005.

${ }^{93}$ Baytelman, "Capacitación...", p. 28.
} 
se habían traducido en un Anteproyecto de Código Procesal Civil. ${ }^{94}$ El Proyecto establece un sistema con muchas similitudes a la LEC 1/2000 de España. Se pone acento en similares principios de oralidad, contradicción, publicidad, se busca potenciar las salidas alternativas a la resolución de conflictos, centra la decisión del conflicto en una audiencia de juicio oral, establece una audiencia preliminar como la audiencia previa, establece un procedimiento sumario parecido al juicio verbal, entre muchas otras consideraciones.

En relación a las observaciones efectuadas de la LEC, el Proyecto chileno de 2009 supera algunos de estos en su articulado. Por ejemplo, no se contempla la posibilidad de declaración de insuficiencia probatoria en la audiencia preliminar ${ }^{95} \mathrm{ni}$ la posibilidad del juez de sugerir prueba en dicha oportunidad. Se establece una distinción entre el interrogatorio efectuado por la parte que presenta el testigo y el que efectúa la contraparte, ${ }^{96}$ y declara que no hay testigos inhábiles, siendo facultad de las partes abordar los temas sobre credibilidad de los testigos. ${ }^{97}$ Se establece, asimismo, que el juez deberá resolver inmediatamente terminado el juicio, con fundamentos breves, garantizando así la inmediación, tras lo cual el fallo completo debe entregarse en 5 días, salvo determinadas excepciones. ${ }^{98}$ Muchas de estas normas recogen la experiencia del sistema procesal oral penal que rige en Chile desde el 2001, algo que deja establecido el ejecutivo en el mensaje del Proyecto.

Sin embargo, se detectan algunas similitudes con la LEC que podrían traer ciertas dificultades a la hora de ponerse en práctica el sistema. Por ejemplo, si bien no se establece expresamente que el juez pueda sugerir prueba en la audiencia preliminar, el artículo 18.4 del Proyecto faculta al juez para "(o) rdenar las diligencias necesarias al esclarecimiento de la verdad de los hechos controvertidos, respetando el derecho de defensa de las partes, en la oportunidad establecida en la ley". La facultad anterior, en los términos amplios en que ha sido planteada, le otorgaría al juez la posibilidad de decretar prueba de oficio en cualquier etapa del procedimiento, lo cual, a juicio de este autor, podría resultar incluso más perjudicial para la imparcialidad del juzgador que la posibilidad que establece la LEC en la audiencia previa. Por otro lado, se ha otorgado competencia al mismo juez del proceso para conocer y fallar sobre

\footnotetext{
${ }^{94}$ En relación a la reforma procesal civil chilena, proyecto, anteproyecto y documentos de discusión es posible obtener la información en el sitio web sobre la Reforma del Ministerio de Justicia de Chile http://web.minjusticia.cl/ucrpc/.

${ }^{95}$ Art. 252 del Proyecto.

${ }^{96}$ Art. 305 del Proyecto.

${ }^{97}$ Art. 284 del Proyecto.

${ }^{98}$ Art. 309 del Proyecto.
} 
la procedencia de las medidas cautelares ${ }^{99}$ Asimismo, se ha hecho una distinción entre la declaración de parte y de testigo y la norma no parece permitir la declaración de la propia parte aún cuando a la luz de la idea de la inexistencia de testigos inhábiles y de libertad probatoria podría buscarse una interpretación acorde a esa posibilidad. ${ }^{100}$

\section{Conclusiones y algunas propuestas}

El proceso civil establecido por la LEC de 2000 sin duda ha representado una transformación radical, teórica y práctica, respecto al sistema procesal civil anterior. Este sistema ha logrado instaurar la oralidad, la inmediación, la contradicción y la publicidad como las bases del proceso, más allá de su instauración en la norma y en las intenciones del legislador. Experiencias comparadas de reformas procesales que han intentado pasar de un sistema escriturado a uno oral han demostrado que no siempre las buenas intenciones del legislador o la mera instauración de la norma en el Código permiten, en la práctica, la consagración de estos principios. Sobran los ejemplos de cambios legislativos que, por diversas razones, no logran concretarse en la práctica, porque la mera modificación de ley, en sí misma, no implica necesariamente un cambio concreto en la realidad. Diseños de políticas públicas que no han incorporado la fase de implementación, costumbres arraigadas en los operadores o actores, resistencias a los cambios, intereses sectoriales, falta de incentivos, problemas de técnica legislativa, etc., son algunas de las múltiples razones posibles. De ahí entonces que el sistema procesal civil español resulta un buen ejemplo a la hora de generar cambios procesales en materia civil, no sólo en el plano legislativo sino también en el campo de implementación práctica del sistema, constituyéndose en un referente necesario para todos aquellos países que han compartido o seguido a España en un mismo sistema de justicia continental o de civil law.

Lo anterior permite a su vez no sólo observar las buenas prácticas y ejemplos del sistema español sino que debe ser un referente necesario también

\footnotetext{
${ }^{99}$ Art. 170 del Proyecto.

${ }^{100}$ El artículo 294 del Proyecto establece: "Procedencia de la declaración de las partes. Cada parte podrá solicitar al juez la declaración oral de las demás partes sobre hechos y circunstancias de los que tengan noticia y que guarden relación con el objeto del juicio. Si los demandantes o demandados fueren varios y se solicitare la citación a declarar en juicio de muchos o de todos ellos, el juez podrá reducir el número de quienes habrán de comparecer, en especial cuando estime que sus declaraciones puedan resultar una reiteración inútil sobre los mismos hechos. La parte citada a declarar estará obligada a concurrir personalmente a la audiencia, a menos que designe especialmente y por escrito un mandatario para tal objeto, el que se entenderá que la representa para todos los efectos legales relacionados con la diligencia, considerándose sus declaraciones como si hubieren sido hechas personalmente por aquél cuya comparecencia fue solicitada. Antes de la declaración de la parte, su apoderado podrá objetar la pregunta formulada y el juez resolverá de plano o previo debate".
} 
para mejorar o avanzar en aquellos puntos que, de ser corregidos, permitirían obtener mejoras en el sistema, considerando que el mismo ha puesto como centro el Juicio Oral, público y contradictorio y entendiendo este como la mejor herramienta para obtener información de calidad que permite decidir al juez. De ahí que este trabajo no haya pretendido hacer sólo alabanzas del sistema español sino que ha perseguido observar algunos aspectos que, a juicio del autor, podrían mejorar la calidad de la información que se produce en juicio lo que a la postre redunda en mejores decisiones $y$, finalmente, en un mejor sistema para los usuarios.

En este sentido, como se señaló en la introducción, este autor ha pretendido levantar problemas en ciertas normas e instituciones que, desde un punto de vista práctico, afectan la calidad de la información y las decisiones que se toman en juicio, para lo cual se ha efectuado no solo un análisis doctrinario y jurisprudencial sino que se ha basado en observación en terreno, entrevista con actores y la experiencia del propio autor. Como se señaló desde un inicio, atendida la extensión y características de este trabajo, no ha pretendido el mismo ser una investigación empírica, ni otorgar cifras representativas, sino simplemente aportar ideas al permanente debate sobre posibles mejoras al sistema de justicia civil en España. Estas ideas por cierto podrían ser debatidas, podrían asimismo encontrarse otros problemas y múltiples soluciones, pero se insiste en que sólo han sido ideas y observaciones que este autor ha recogido y analizado brevemente para contribuir al debate en España y en Chile, en donde existe un Proyecto de Código Procesal Civil y un proceso de reforma en curso que, entre otros, ha puesto sus ojos en el sistema español.

Haber instaurado un sistema con base en la oralidad, la contradicción, la inmediación, la imparcialidad, la publicidad, etc., sólo tiene lógica si lo que se ha perseguido es, entre otras cosas, mejorar la calidad de las decisiones judiciales y de las respuestas del sistema de justicia frente a los requerimientos de sus usuarios, los ciudadanos. Es en este entorno en el cual se han presentado los problemas expuestos en este trabajo y en el cual se hacen las propuestas.

En primer lugar, a efectos de garantizar la inmediación del juez, sería importante que se estableciese una obligación para que los jueces emitieran su veredicto una vez concluido el debate y las conclusiones de las partes, sin que transcurriese un tiempo tan prolongado como el dispuesto por la LEC. En la práctica, en la mayoría de los casos los jueces al terminar el juicio ya tienen claro cuál será su veredicto por lo que esto no debiese tener mayores consecuencias. La norma de la LEC y la falta de una sanción expresa por el transcurso prolongado de tiempo han permitido en la práctica que muchas sentencias se emitan incluso meses después de realizados los juicios. Para que ello sea así resulta inevitable entonces que muchos jueces deban necesariamente recurrir a sus notas y a la carpeta existente en el tribunal, perdiéndose gran parte del valor 
que tiene la apreciación directa de la prueba y las conclusiones que sobre ella se desprenden. Resulta evidente que en ocasiones el juez requerirá preparar su breve fundamentación o tomarse un breve tiempo para decidir su veredicto, tratándose de casos altamente complejos o de larga duración, los cuales son la excepción. Así, resulta posible establecer excepciones a una medida como esta, excepciones que deben ser establecidas a modo de regla, no de estándar, para evitar problemas interpretativos. Es perfectamente posible fijar un plazo mayor para la redacción integra del fallo y los argumentos, pero esto no impide el veredicto y una breve fundamentación terminado el juicio.

En segundo lugar, a efectos de garantizar los objetivos perseguidos por la contradicción, sería importante efectuar una serie de modificaciones. Recordemos que lo que se busca con la contradicción es someter a un control de calidad las pruebas presentadas por la contraparte, control de calidad que, por un lado, está en mejores condiciones de hacer el posible afectado y, en segundo lugar, no debiese quedar en manos del mismo juez que decide so riesgo de que se vea afectada su imparcialidad. De esta forma, pareciera necesario modificar la regulación sobre el procedimiento de acreditación de partes, testigos y peritos, debiendo ser una facultad de las partes efectuar las preguntas que estimen pertinentes para acreditar al declarante o el testimonio y prohibiendo que sea el juez quien indague y realice preguntas sobre esta situación, limitando su actuación en este punto a las preguntas de identificación y, principalmente, a las advertencias legales sobre las consecuencias de la declaración.

Sería necesario también para garantizar la contradicción establecer una regulación más clara respecto al tipo de preguntas que puede realizar quien presenta al declarante y las preguntas que puede hacer la contraparte, y del sistema de objeciones a las mismas. Los objetivos que persiguen unas y otras y la disposición del declarante para con cada uno de los litigantes es radicalmente distinta por lo que las normas deben dar cuenta y reflejar esta diferencia, evitando así un perjuicio a la parte que no presenta al declarante. Otra modificación para garantizar la contradicción es establecer de forma expresa la posibilidad de formular conclusiones en el juicio verbal. No parece razonable que esto quede a discreción de cada juez o Audiencia Provincial, ya que una interpretación que no la permita privará a las partes de presentar al juez con claridad cuál es la información que se ha vertido en juicio y como ella calza con su versión del litigio. Asimismo, no permitir expresamente esta facultad en un entorno con alto volumen de trabajo -y más considerando el posible aumento de cuantíapuede generar interpretaciones altamente restrictivas del derecho de las partes a mostrar en juicio su versión del caso.

Por otro lado, para garantizar la contradicción y garantizar que la información con la cual resuelva el juez el pleito sea la mejor posible resulta necesario permitir la declaración de la propia parte. En la medida que esa parte tenga 
información útil para el juicio y que esa información pueda ser sujeta a un test de calidad mediante la contradicción, no parece razonable que quede entregado a la contraparte el decidir estratégicamente solicitar o no la declaración de la parte, tal como sucede en la práctica. Finalmente, tenga el nombre de testigo o parte, lo que importa en juicio es el contenido de la declaración que efectúa, la información que aporta, con lo cual no se diferencia en este punto del testigo o del perito como fuente de información. Con ello se está afectando la posibilidad de presentar prueba ante un tribunal y de mostrar, con todos los medios pertinentes, que mi versión del litigio es la adecuada con el ordenamiento jurídico, pudiendo incluso estarse en presencia de una vulneración constitucional, como ya lo han sugerido algunos autores citados en este trabajo.

A efectos de garantizar de mejor forma la imparcialidad del juez se hace necesario eliminar y modificar ciertas normas que, en la práctica, pueden resultar atentatorias con este principio. Una primera medida ya indicada consiste en suprimir la posibilidad del juez de efectuar preguntas de acreditación de los declarantes, quedando éstas a cargo de las partes y siendo única responsabilidad del juez la de acreditar la identidad del declarante y efectuarle las advertencias legales, sin perjuicio de las preguntas aclaratorias. Una segunda medida necesaria, a juicio de este autor, es eliminar la facultad del juez para decretar la insuficiencia probatoria y proponer una prueba. Si el juez estima que el caso no tiene futuro ya dictará una sentencia absolutoria o bien es posible crear una norma que le permita dictar un fallo finalizada la audiencia previa en donde ponga término al caso por dicho motivo. Lo que no es posible es que el juez termine beneficiando a una de las partes con su intervención. Así parece haberse entendido en la práctica, en donde los jueces no utilizan esta facultad precisamente porque entienden que atenta con su imparcialidad. En este mismo orden, para garantizar la imparcialidad del juez también es necesario eliminar la posibilidad que tiene el juez para decretar de oficio -e incluso a petición de parte- diligencias finales, quedando sólo la posibilidad ante prueba nueva. No sólo está en juego la imparcialidad del juez sino que también puede constituirse en una vía dilatoria del proceso, más aún, atendida la alta carga de trabajo que existe actualmente.

En relación con la imparcialidad y considerando los cambios estructurales que se encuentran actualmente en trámite, resulta altamente recomendable en pro de la imparcialidad del juez establecer que el juez que conozca de las medidas cautelares sea uno distinto del que decidirá del juicio oral. Ciertamente los principios admiten una valoración distinta según sean las circunstancias e intereses en juego, pero sea cual sea la decisión, corresponde al legislador hacerse cargo seriamente sobre el porqué se opta por uno u otro. Así, no siendo una medida muy recurrente en la práctica, estando en pie una reforma orgánica de funcionamiento, y reconociendo indirectamente el legislador que la no di- 
visión atenta contra la imparcialidad, no se justifica que no pueda procederse a la división de esta atribución.

Pero la consolidación y perfeccionamiento de un sistema basado en la litigación en audiencias orales y contradictorias requieren no sólo de modificaciones legales y de la disposición de recursos, requiere también que los actores que operan día a día en los mismos tengan las herramientas para sacar el mejor provecho posible al sistema. De ahí que sea necesaria una solida preparación de quienes intervienen en las audiencias, preparación que no se agota en un acabado estudio de la legislación, de la jurisprudencia y de las prácticas que se requieren a diario para participar del sistema. Las técnicas de litigación oral, el aprendizaje de las mismas, son herramientas que permiten en definitiva obtener la mejor información del juicio. Estas técnicas se verán beneficiadas por un ejercicio cotidiano en la práctica, y probablemente habrá muchos que puedan aprender estas de forma instintiva por el solo ejercicio de la profesión de litigante. Sin embargo, existirá siempre otro porcentaje que no tendrá esa habilidad y la falta de preparación se traduce finalmente en un sistema que toma decisiones de menor calidad por falta de mejor información. De ahí que parezca importante fomentar el desarrollo de cursos de técnicas de litigación en juicio oral, en pre y posgrado, no sólo de cursos sobre la doctrina, la jurisprudencia y como realizar una mejor demanda, sobre todo considerando la gran cantidad de profesionales con amplia experiencia profesional y académica en países con sólidos modelos de litigación oral -aun cuando ello per se no garantiza el manejo de estas herramientas- y la tendencia a la oralización de los procesos.

A juicio de este autor, a pesar de la influencia de la LEC sobre el mismo, el Proyecto de Código Procesal Civil de Chile, ha mejorado algunos de los aspectos problemáticos presentados en este trabajo, cambios que deberían contribuir en la práctica a la toma de decisiones con mejor información. Probablemente, mucha influencia ha tenido la experiencia práctica acumulada a propósito de la reforma procesal penal del año 2001, sin embargo, existen otros problemas mencionados en este trabajo que se mantienen en el proyecto chileno, problemas que, en la práctica, pueden afectar la vigencia de esos principios trascendentales que dan sustento al sistema y la calidad de la información y decisiones que surjan del mismo.

Por último, tal como se comentó en la introducción, cabe reiterar que muchos de los temas abordados en este trabajo deberían tenerse en consideración a propósito de la reforma a la Ley de Enjuiciamiento Criminal española que se encuentra en actual discusión, puesto que, a juicio de este autor, serán de gran trascendencia para la efectiva consolidación en la práctica del modelo que se pretende instaurar. En este punto, probablemente la experiencia de las últimas décadas en América Latina tiene y tendrá mucho que aportar en esta discusión. 
Como quedó de manifiesto en partes de este trabajo, muchos de estos problemas responden o sólo encuentran su incorporación en decisiones políticas respecto a cómo queremos que funcione nuestro sistema de justicia. Todo proceso de reforma debe necesariamente poner en la balanza distintos intereses en juego, posturas de diferentes actores, incluyendo aquellas opiniones influyentes pero resistentes a los cambios. Habiendo transcurrido 10 años desde la vigencia de la LEC, probablemente habiéndose demostrado que muchas de las opiniones provenientes de sectores resistentes a la reforma no tenían asidero en la práctica, avanzar en el perfeccionamiento del sistema resulta indispensable para mejorar la calidad de la información y decisiones que este genera, y concretar en la práctica todos aquellos principios que esta dice incorporar pero no siempre garantizar.

\section{BibLIOGRAFíA}

Abel, Xavier; Pico I Junor, Joan (Coordinadores), Problemas actuales de la prueba civil, Ed. Bosch, Barcelona, 2005.

Abel, Xavier y Pico I Junor, Joan (Directores), Aspectos Prácticos de la Prueba Civil, Ed. Bosch, Barcelona, 2006.

Abel LlunCh, Xavier (Director), El interrogatorio de las partes en la Ley 1/2000, de Enjuiciamiento Civil, Ed. Bosch, Barcelona, 2008.

Baytelman, Andrés y Duce, Mauricio, Litigación Penal, Juicio Oral y Prueba, Ed. Universidad Diego Portales, Santiago, 2004.

Baytelman, Andrés, "Capacitación como fútbol". En Revista Sistemas Judiciales $N^{\circ} 1,19$ de agosto de 2002, Centro de Estudios de Justicia de las Américas, Santiago, Chile.

Binder, Alberto, "Elogio de la Audiencia Oral y Pública". Ponencia presentada en el XXVI Congreso Nacional de Derecho Procesal, Universidad Nacional del Litoral. Santa Fe, Argentina. Junio de 2011.

Centro de Estudios de Justica de las Américas, Justicia Civil: Perspectivas para una reforma en América Latina, Ed. Centro de Estudios de Justicia de las Américas, Santiago, 2008.

Centro de Estudios y Asistencia Legislativa, Pontificia Universidad Católica de Valparaíso de Chile. Estudio "Levantamiento de información y análisis de modelos orgánicos comparados", Vol. 1. Abril de 2006, Valparaíso.

Comisión de Demarcación y Planta, "Informe de la Comisión sobre Demarcación y Planta", Ministerio de Justicia de España, Madrid, 2010.

Consejo General del Poder Judicial, Informe "La Justicia Dato a Dato. Año 2009", España, 2010.

Consejo General del Poder Judicial. Informe "Avance 2010", España, 2011. 
ChICo F., Tania, "La Facultad del Juez de indicar la insuficiencia de la prueba propuesta y la preclusión probatoria. A propósito del art. 429.1, II de la ley de enjuiciamiento civil", en En Abel Ll. X. y Pico I Junor (Dirs.), Aspectos Prácticos de la Prueba Civil, Ed. Bosch, Barcelona, 2006.

CucArella G., Luis-Andrés, "El trámite de las conclusiones en el juicio verbal", en CARPI y ORTells (Ed.), Oralidad y escritura en un proceso civil eficiente, Vol. II, Ed. Universitat de Valencia, Valencia, 2008.

DuCE, Mauricio y Riego, Cristián, Proceso Penal, Ed. Jurídica de Chile. Santiago, 2007.

DuCE, Mauricio; Marín, Felipe; Riego, Cristián, "Reforma a los procesos civiles orales: consideraciones desde el debido proceso y calidad de la información". En Justicia Civil: Perspectivas para una reforma en América Latina, Ed. Centro de Estudios de Justicia de las Américas, Santiago, 2008.

Gómez C., Juan L. y otros, Derecho Jurisdiccional, Vol. II Proceso Civil, Ed. Tirant Lo Blanch, 18 ed., Barcelona, 2010.

Gómez M., Carlos (Director), La Imparcialidad Judicial, Estudios de Derecho Judicial № 151, Consejo General del Poder Judicial, Madrid, 2009.

Guerrero P., Salvador, La Imparcialidad Objetiva del Juez Penal, Ed. Aranzadi. Navarra, 2009.

Gutiérrez-Alviz C. Faustino (Director), Exposición de la nueva Ley de Enjuiciamiento Civil, Ed. Tirant lo Blanch, Valencia, 2001.

JıménEz A., Rafael, Imparcialidad Judicial y Derecho al Juez Imparcial, Ed. Aranzadi, Navarra, 2002.

LoRedo C., Marcos, "Comentarios prácticos a la Ley de Enjuiciamiento Civil: La imparcialidad en el proceso civil: el deber de abstención. Arts. 99, 100 y 102 a 106 LEC". Revista InDret 2/2009. Barcelona, mayo de 2009.

LOREDO C., Marcos, "Comentarios prácticos a la Ley de Enjuiciamiento Civil: La imparcialidad en el proceso civil: el derecho a recusar. (artículos 99, 101 y 107 a 128 LEC". Revista InDret 3/2009. Barcelona, julio de 2009.

Maroto M., Joaquín, "El Juicio Verbal", en Gutiérrez-Alviz C. Faustino (Director), Exposición de la nueva Ley de Enjuiciamiento Civil, Ed. Tirant lo Blanch, Valencia, 2001.

Ministerio de Justicia De Chile. "Proyecto de Código Procesal Civil". Santiago, 2009.

Montero A., Juan y otros, Derecho Jurisdiccional, Vol. I Parte General, Ed. Tirant Lo Blanch, $18^{\circ}$ ed., Barcelona, 2010.

Montero A., Juan, La Prueba en el Proceso Civil, Ed. Civitas, 6 a ed., Navarra, 2011.

MOntero A., Juan, Sobre la imparcialidad del juez y la incompatibilidad de funciones procesales, Ed. Tirant lo Blanch, Valencia, 1999. 
Ortells R., Manuel, Derecho Procesal Civil, Ed. Aranzadi, Navarra, $10^{\circ}$ ed., 2010.

Palomo V., Diego, La oralidad en el proceso civil. El nuevo modelo español, Ed. Librotecnia, Santiago, 2008.

Ramos M., Francisco, Enjuiciamiento Civil. Como gestionar los litigios civiles, Tomos I y II, Ed. Atelier, Barcelona, 2008.

Ríos L., Yolanda, “¿Puede el juez, al amparo del art. 429.1, II LEC, proponer una fuente de prueba distinta de la ya propuesta por las partes? ¿Es necesario que la prueba propuesta conste nominatim en los autos, o basta que se desprenda de los mismos?", en ABEL, Xavier y PICo I Junor, Joan. Problemas actuales de la prueba civil, Ed. Bosch, Barcelona, 2005.

Rodríguez F., Ricardo, "La imparcialidad objetiva o la denominada 'contaminación procesal' (el derecho a un juez no prevenido)". Cuadernos de derecho judicial, № 6, Madrid, 1996.

Salvador C., Pablo; Gómez L., Carlos; De La Fuente, Ángel; Collado, Roberto; VÁsquez, Pablo, Reformas necesarias para potenciar el crecimiento de la economía española, Vol. I: Justicia, Financiación autonómica y Sanidad, Ed. Civitas, Navarra, 2011.

Solano M. Miriam, "Incidencia de la oralidad en la formulación de las conclusiones: de la instructa a las conclusiones orales" en ABEL LI. y PICO I JUNOI, (Dir), Aspectos Prácticos de la Prueba Civil, Ed. Bosch, Barcelona, 2006.

Torres P., David, "Aspectos subjetivos en el interrogatorio de las partes", en ABel LI. X. y Pico I Junor (Dir), Aspectos Prácticos de la Prueba Civil, Ed. Bosch, Barcelona, 2006. 
